100-N Area Strontium-90 Treatability Demonstration Project:

Food Chain Transfer Studies

for Phytoremediation Along

the 100-N Columbia River

Riparian Zone

\author{
RJ Fellows \\ JS Fruchter \\ CJ Driver
}

April 2009 


\title{
DISCLAIMER
}

This report was prepared as an account of work sponsored by an agency of the United States Government. Neither the United States Government nor any agency thereof, nor Battelle Memorial Institute, nor any of their employees, makes any warranty, express or implied, or assumes any legal liability or responsibility for the accuracy, completeness, or usefulness of any information, apparatus, product, or process disclosed, or represents that its use would not infringe privately owned rights. Reference herein to any specific commercial product, process, or service by trade name, trademark, manufacturer, or otherwise does not necessarily constitute or imply its endorsement, recommendation, or favoring by

the United States Government or any agency thereof, or Battelle Memorial Institute. The views and opinions of authors expressed herein do not necessarily state or reflect those of the United States Government or any agency thereof.

\author{
PACIFIC NORTHWEST NATIONAL LABORATORY \\ operated by \\ BATTELLE \\ for the \\ UNITED STATES DEPARTMENT OF ENERGY \\ under Contract DE-AC05-76RL01830
}

Printed in the United States of America

Available to DOE and DOE contractors from the

Office of Scientific and Technical Information,

P.O. Box 62, Oak Ridge, TN 37831-0062;

ph: (865) 576-8401

fax: (865) 576-5728

email: reports@adonis.osti.gov

\author{
Available to the public from the National Technical Information Service, \\ U.S. Department of Commerce, 5285 Port Royal Rd., Springfield, VA 22161 \\ ph: (800) 553-6847 \\ fax: (703) 605-6900 \\ email: orders@ntis.fedworld.gov \\ online ordering: http://www.ntis.gov/ordering.htm
}

This document was printed on recycled paper. 


\section{0-N Area Strontium-90 Treatability Demonstration Project: Food Chain Transfer Studies for Phytoremediation Along the 100-N Columbia River Riparian Zone}

RJ Fellows

JS Fruchter

CJ Driver

April 2009

Prepared for

the U.S. Department of Energy

under Contract DE-AC05-76RL01830

Pacific Northwest National Laboratory

Richland, Washington 99352 



\section{Summary}

Strontium-90 $\left({ }^{90} \mathrm{Sr}\right)$ exceeds the U.S. Environmental Protection Agency's drinking water standards for groundwater ( 8 picocuries/L) by as much as a factor of 1000 at several locations within the Hanford $100-\mathrm{N}$ Area and along the 100-N Area Columbia River shoreline. The isotope is present both in the aquifer near the river and in the vadose and riparian zones of the river's shore.

Phytoremediation (or more specifically phytoextraction) is a managed remediation technology in which plants or integrated plant/rhizosphere systems are employed to phytoextract and/or sequester soil contaminants. Phytoextraction of ${ }^{90} \mathrm{Sr}$ is being considered as a potential remediation system along the riparian zone of the Columbia River as part of a treatment train that includes an apatite barrier to immobilize groundwater transport of ${ }^{90} \mathrm{Sr}$. Phytoextraction would employ coyote willow (Salix exigua) to extract ${ }^{90} \mathrm{Sr}$ from the vadose zone soil and aquifer sediments (phytoextraction) and filter ${ }^{90} \mathrm{Sr}$ (rhizofiltration) from the shallow groundwater along the riparian zone of the Columbia River. The stem and foliage of coyote willows accumulating ${ }^{90} \mathrm{Sr}$ may present not only a mechanism to remove the contaminant but also can be viewed as a source of nutrition for natural herbivores, therefore becoming a potential pathway for the isotope to enter the riparian food chain.

Engineered barriers such as large and small animal fencing constructed around the field plot will control the intrusion of deer, rodents, and humans. These efforts, however, will have limited effect on mobile phytophagous insects. Therefore, this study was undertaken to determine the potential for food chain transfer by insects prior to placement of the remediation technology at 100-N. Insect types include direct consumers of the sap or liquid content of the plants vascular system (xylem and phloem) by aphids as well as those that would directly consume the plant foliage such as the larvae (caterpillars) of Lepidoptera species.

Our previous study demonstrated again that coyote willows would accumulate ${ }^{90} \mathrm{Sr}$ from $100-\mathrm{N}$ soil (sediment). The plants accumulated greater than $10 \%$ of the total activity contained in the pots that were transported into the above-ground shoot within 60 days.

Heavy infestations of aphids ( $>2000$ aphids/plant) feeding on the stems and leaves of willows growing in $100-\mathrm{N}^{90} \mathrm{Sr}$-contaminated soil accumulated only a small amount $(2.2 \pm 0.7 \mathrm{pCi})$ of the total label present in the plant $\left(>1200 \mathrm{pCi}\right.$ ) over a 17-day exposure period. The ${ }^{90} \mathrm{Sr}$ in the exuded honeydew during this 17-day period amounted to $2.04 \pm 0.17 \mathrm{pCi} /$ plant. The honeydew would eventually be deposited into the soil at the base of the plant, but the activity would be so dispersed as to be undetectable.

Moth larvae feeding on ${ }^{90} \mathrm{Sr}$-contaminated leaves from $100-\mathrm{N}$ soil grown plants contained 1 to $2 \mathrm{pCi}$ of ${ }^{90} \mathrm{Sr} /$ larvae. The ${ }^{90} \mathrm{Sr}$ was not retained in the insect once their digestive tracts were cleared. Pupating and adult moths also contained no detectable amounts of ${ }^{90} \mathrm{Sr}$. The lack of label may also indicate that the adults would not continue feeding on willows but seek other food sources. Over the 10-day exposure period, $\sim 0.16 \%$ of the phytoextracted ${ }^{90} \mathrm{Sr}$ was lost from the plant as moth feces. However, like the aphid honeydew, moth larvae feces dispersed into the soil were undetectable. Any loss of ${ }^{90} \mathrm{Sr}$ to the ground below the plants either as aphid honeydew or as moth larvae feces would only occur if and when the insects were present. Further with time, as the plant diminishes the content of ${ }^{90} \mathrm{Sr}$ in the soil with uptake and dry matter removal following harvests, the activity of the label in the leaves and new stems would also diminish. 
Birds performing secondary consumption of insect herbivores (moth larvae as they feed on trees) may present a slight risk of transfer of the label present in the moth digestive tract to the bird. While ${ }^{90} \mathrm{Sr}$ has been reported to have low or little biotransfer in laboratory feeding experiments, it has not been definitively shown in the field. A conservative approach would be to explore the use of bird netting over the fenced plot along the shoreline to restrict bird access to the plants.

The results of these studies indicate that the risk for detectable transfer of ${ }^{90} \mathrm{Sr}$ from willow trees growing in the contaminated soil along the 100-N shoreline through the food chain of herbivorous insects would be very slight to non-existent. 


\section{Acknowledgments}

Funding for this project was provided by U.S. Department of Energy EM-22. The authors would like to acknowledge the generosity and advice of Drs. Peter Landolt and Tom Unruh of the USDA-ARS

Yakima Agricultural Research Laboratory in Wapato, WA, who supplied the insect cultures. We would also thank Rick Herrington and Danielle Saunders for their excellent technical help during the study. 



\title{
Acronyms and Abbreviations
}

\author{
${ }^{90} \mathrm{Sr}$ \\ Strontium-90 \\ ${ }^{90} \mathrm{Y}$ \\ Yttrium-90 \\ CR \\ concentration ratio \\ DOE \\ U.S. Department of Energy \\ OBLR \\ oblique-banded leaf roller \\ $\mathrm{pCi}$ \\ picocuries \\ PNNL \\ Pacific Northwest National Laboratory \\ USDA-ARS \\ U.S. Department of Agriculture's Agricultural Research Service
}





\section{Contents}

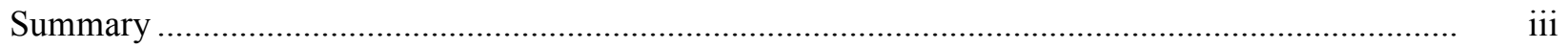

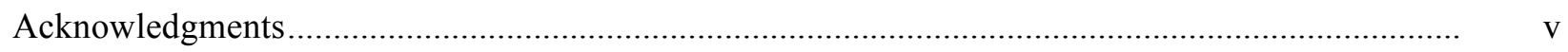

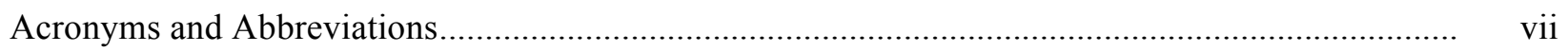

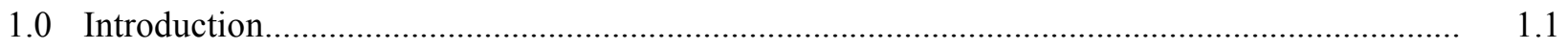

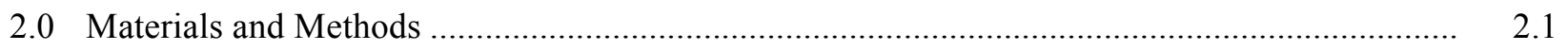

2.1 Sediment Selection and Activity Determination .......................................................... 2.1

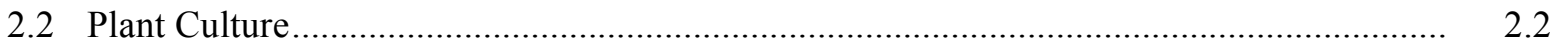

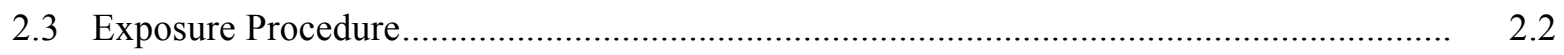

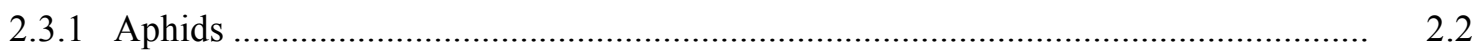

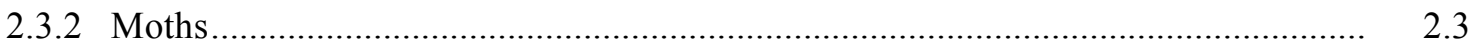

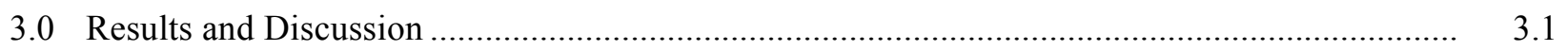

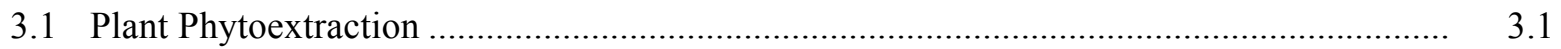

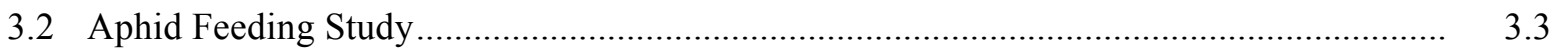

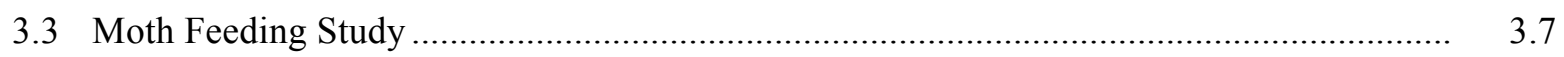

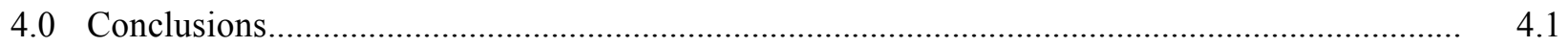

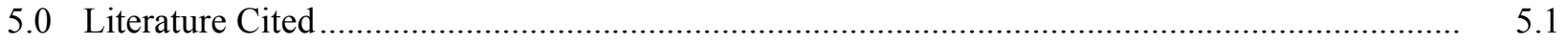

\section{Figures}

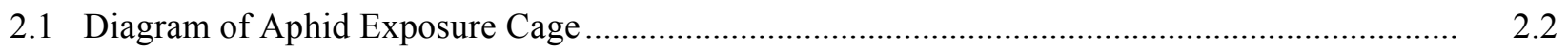

2.2 OBLR Feeding on Control Coyote Willow Leaf .................................................................... 2.4

2.3 OBLR Larvae Prior to Placement on Coyote Willows ….......................................................... 2.5

2.4 OBLR Placed onto the Stem of Coyote Willow in the Exposure Cage Climbing Toward the Leaves.

2.5 OBLR Placed on Control Tissue to Clear its Digestive Tract Following the 10-Day

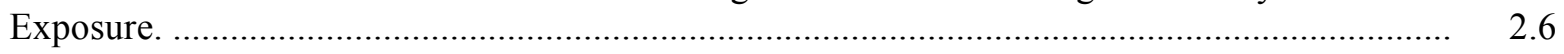

3.1 Aphid Colonization of Willow Stems 3 Days After the Start of the Exposure ........................... 3.4

3.2 Image of Aphids and Their Excretory Honeydew on Coyote Willows Grown in ${ }^{90}$ Sr-Contaminated 100-N Sediment.

3.3 Exposure Chamber and One of Six Plants Used in Moth Experiment ...................................... 3.8

3.4 OBLR on ${ }^{90} \mathrm{Sr}$ Grown Coyote Willow After 10 Days Exposure ............................................... 3.8 


\section{Tables}

2.1 Soils Used for the Aphid and Moth Studies.

3.1 Plant Height, Amount, and Activity of 100-N Sediment Used/Plant and the Soil Acid Extractable ${ }^{90}$ Sr Activity Before and After 60 Days of Plant Growth for the Aphid and Moth Experiments

3.2 Willow Leaf-Specific Activity, the Total Recovered ${ }^{90} \mathrm{Sr}$ in the New Growth Stems and Leaves on Each Plant, and the Percent of Total Recovered ${ }^{90} \mathrm{Sr}$ Activity Distribution Between New Growth Leaves and Stems

3.3 Soil Acid Extractable and Leaf ${ }^{90} \mathrm{Sr}$ Specific Activity and ${ }^{90} \mathrm{Sr}$ Porewater Activity Used to Calculate the Willow Concentration Ratios.

3.4 Dry Wt of Aphid Population Collected From Exposed Plants and Estimation of Total Aphid Number on the Plants After 7- and 17-Days Exposure.

3.5 Specific Activity and Percent Distribution of Total Recovered Activity of ${ }^{90} \mathrm{Sr}$ in Tissue, Aphids, and Aphid Honeydew Following Aphid Exposure to Plants Grown in

${ }^{90} \mathrm{Sr}$-Contaminated 100-N Sediment.

3.6 Observed Amounts and Activities of Aphid Honeydew Collected From Plants Grown in ${ }^{90}$ Sr-Contaminated 100-N Sediment and Infested with Aphids

3.7 ${ }^{90} \mathrm{Sr}$ Activity in pCi and Fresh and Dry Wts of OBLR Larvae at the Time of Harvest From the Contaminated Plants, Following a 48-H Exposure to Control Leaves, the Empty Chrysalis, as Adults, and the Feces Produced by the Larvae During Exposure

1.1 Calculated Average Larval Dry Wt, Fecal Production Rate, and ${ }^{90} \mathrm{Sr}$ Loss to Environment at Time of Harvest Following 10-Day Exposure Period to ${ }^{90}$ Sr Contaminated Coyote Willows.....

1.2 Plant Shoot (Trunk, Stems, and Leaves), Larval, and Fecal Activity Expressed as Both pCi of ${ }^{90} \mathrm{Sr}$ and Percent of Total Recovered ${ }^{90} \mathrm{Sr}$ for Each Plant.

3.10 Calculated Exposure Level of ${ }^{90} \mathrm{Sr}$ to Red-Winged Blackbirds Based on the Premise of Exclusive Feeding on Moth Larvae Eating Leaves on Coyote Willow Trees Growing at $100-\mathrm{N}$. 


\subsection{Introduction}

Strontium-90 $\left({ }^{90} \mathrm{Sr}\right)$ exceeds the U.S. Environmental Protection Agency's drinking water standards for groundwater $(8$ picocuries $[\mathrm{pCi}] / \mathrm{L})$ by as much as a factor of 1,000 at several locations within the Hanford 100-N Area and along the 100-N Area Columbia River shoreline (Figure 1.1A). The isotope is present both in the aquifer near the river and in the vadose and riparian zones of the river's shore. A radiological survey of shoreline vegetation along the Hanford Reach found areas where the vegetation exhibited elevated levels of radionuclides, including the $100-\mathrm{N}$ Area where elevated ${ }^{90} \mathrm{Sr}$ was found in a number of plant species (Antonio et al. 1993, Van Verst et al. 1998, Poston et al. 2000).

Because of its 28 -year half life and relatively high retardation coefficient, the ${ }^{90} \mathrm{Sr}$ that will ultimately reach the Columbia River in bulk lies in the vadose and riparian zones. ${ }^{90} \mathrm{Sr}$ is bound to the sediments in a relatively thin layer, the top of which corresponds to the upper boundary of an elevated water table formed during the active disposal period (1963-1991). The approximately 5-m wide riparian zone is also shallow (0.2-1.5 m; Figure 1.1B). The soil/sediment strontium (both stable and fission product) is held primarily via an ion-exchange mechanism that retards $\mathrm{Sr}$ and ${ }^{90} \mathrm{Sr}$ transport (Serne and LeGore 1996). The sorption coefficient $\mathrm{K}_{\mathrm{d}}$ for the ${ }^{90} \mathrm{Sr}$ is between 15 and $40 \mathrm{~mL} / \mathrm{g}$, which means that at least $99 \%$ of the ${ }^{90} \mathrm{Sr}$ is sorbed to the sediment, with the remaining $1 \%$ associated with the groundwater.
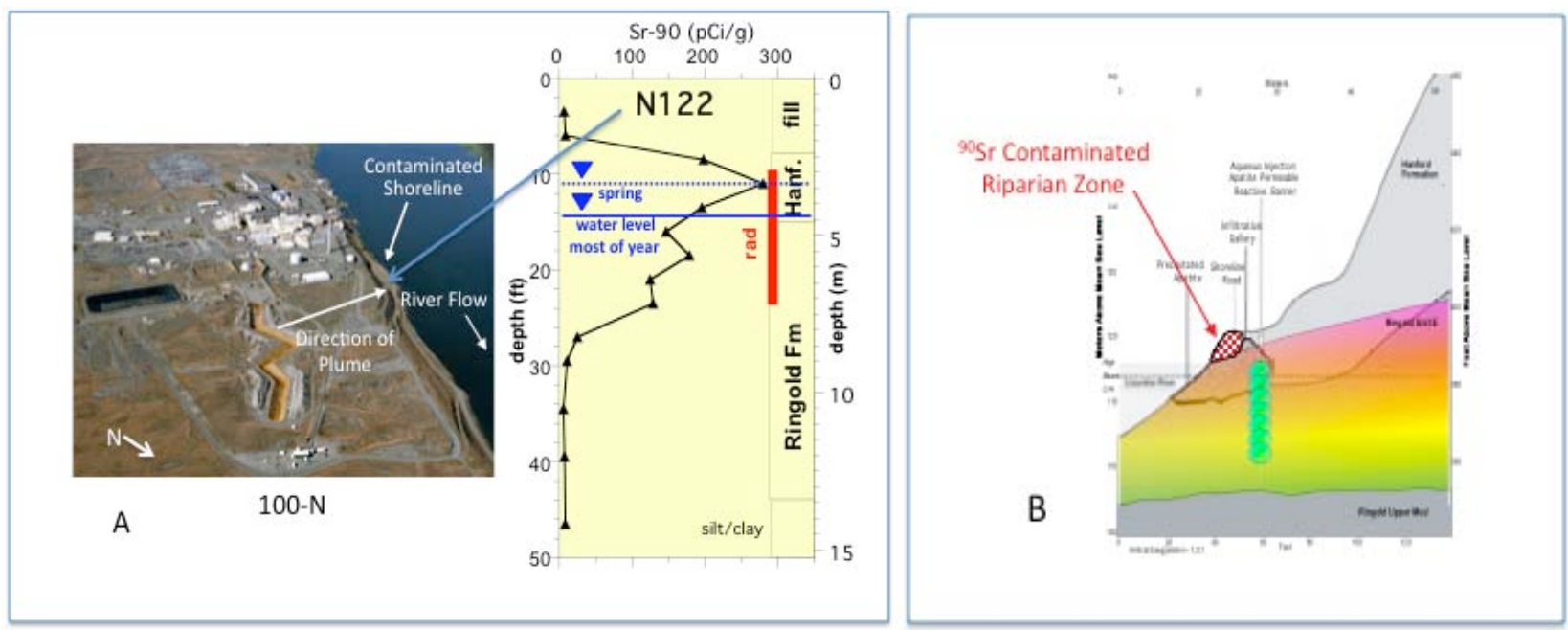

Figure 1.1. (A) Picture of $100-\mathrm{N}$ and Accompanying ${ }^{90} \mathrm{Sr}$ Activity Graph at Sampling Well $(\mathrm{n}=122)$ Whose Location is Shown by Arrow Along Columbia River Shoreline; (B) Diagram Showing Positions of ${ }^{90} \mathrm{Sr}$-Contaminated Riparian Zone Along Columbia River Shoreline and Proposed Position of Permeable Apatite Barrier

Phytoremediation (or more specifically phytoextraction) is a managed remediation technology in which plants, or integrated plant/rhizosphere systems, are employed to phytoextract and/or sequester soil contaminants (Pilon-Smits 2005, Pulford and Watson 2003, INEEL 2000). Phytoextraction of ${ }^{90} \mathrm{Sr}$ has been reported as a potential method managing radioactively contaminated sites (Willey and Collins 2007, Vandenhove 2006, Dutton and Humphreys 2005) and is considered a potential remediation system along the riparian zone of the Columbia River as part of a treatment train that includes an apatite barrier. Through calcium-citrate-phosphate injections into the riverbank soil, the apatite barrier would immobilize groundwater transport of ${ }^{90} \mathrm{Sr}$ (Figure 1.1B). The barrier is designed to sequester and/or precipitate ${ }^{90} \mathrm{Sr}$ 
currently present in the vadose zone soil porewater as well as that expected to move with the groundwater through the soil below the bluff toward the river over the next 300 years.

Located between the injection field and the river, the phytoextraction system is a polishing step directed at ${ }^{90} \mathrm{Sr}$ extraction from the vadose and saturated (riparian) zones at the Columbia River shoreline. Once the apatite barrier is fully functional and the riparian zone ${ }^{90} \mathrm{Sr}$ is extracted, the phytoextraction component of the treatment train would be discontinued. In addition, there will be an anticipated synergy between the placement of the apatite sequestration barrier and the phytoextraction process that arises from an established willow rhizosphere (root zone). This area will act as a filter (rhizofiltration) of ${ }^{90} \mathrm{Sr}$ from groundwater mobilized during the injection of the apatite solution and ahead of the apatite precipitation front.

The unique 100-N Area riverbank setting is dominated by course-grained sands, is subjected to significant daily fluctuations in groundwater level, and is covered with rip-rap. In this environment, implementation of a phytoremediation strategy requires a plant with roots capable of invading the saturated zone and with an inherent ability to tolerate water-table fluctuations. The phytoextraction technology employs plants, specifically coyote willow (Salix exigua), to extract ${ }^{90} \mathrm{Sr}$ from the vadose zone soil and aquifer sediments (phytoextraction) and filter ${ }^{90} \mathrm{Sr}$ (rhizofiltration) from the shallow groundwater along the riparian zone of the Columbia River. Coyote willow is a perennial native shrub that grows along the Columbia River throughout the Hanford Site and Mid-Columbia region. As a phreatophyte, the willow's root system readily invades the saturated zone and tolerates prolonged flooding. The plant is easily propagated by above-ground cuttings, spreads by lateral root suckers (minimizing planting problems), and is amenable to multiple harvests in a given year without the need to replant.

Phytoremediation would act as an immediate interceptor of aqueous ${ }^{90} \mathrm{Sr}$ currently within the riparian zone's pore water and a longer term extractor of ${ }^{90} \mathrm{Sr}$ currently sorbed to the riparian zone's vadose and aquifer sediment. Without the ability to prevent future transport of ${ }^{90} \mathrm{Sr}$ into the riparian zone (barrier placement), phytoremediation would not be an appropriate remediation technology. Combined with the barrier, it could be an effective, low cost/maintenance remediation technology (U.S. Department of Energy [DOE] 2005).

The stem and foliage of coyote willows growing along the Columbia River shoreline and accumulating ${ }^{90} \mathrm{Sr}$ may present not only a mechanism to remove the contaminant but also will be viewed as a source of nutrition for natural herbivores and therefore a potential pathway for the isotope to enter the riparian food chain. When ingested, ${ }^{90} \mathrm{Sr}$ generally accumulates in non-consumable tissues (bones and exoskeletons); therefore, it has been shown that little or no biomagnification of ${ }^{90} \mathrm{Sr}$ isotope occurs in increasingly higher levels of the food chain (Carraca et al. 1990, Reichle and Crossley 1969). However, direct consumers may themselves become contaminated and transport the isotope offsite (Mietelski et al. 2004). To obviate this, a series of engineered barriers will be constructed around the field plot. Large and small animal fencing will control the intrusion of herbivores such as deer and rodents and omnivores such as man. Bird intrusion would be minimized through the placement of netting over the top of the enclosure. Detritus, including abscised leaves and twigs, would be retained within the plot by the fencing and removed through weekly policing. Removing the foliage twice yearly (before flowering and pollen release [April-May] and prior to leaf drop [September-October]) will also reduce detritus production. These efforts, however, will have limited effect on mobile phytophagous insects. Management practices such as pesticide application have limited acceptability given the proximity to the Columbia River. Therefore, it is essential that a determination of the potential for food chain transfer by insects be addressed prior to the technology placement at 100-N. 
This study sought to evaluate the potential for ${ }^{90} \mathrm{Sr}$ contamination from insects that consume plant material grown in 100-N soil contaminated with ${ }^{90} \mathrm{Sr}$. There are three major means by which resident and transitory insects may accumulate ${ }^{90} \mathrm{Sr}$ from the tissues of the coyote willow: consumption of pollen, sap, and/or the foliage and tender shoots. The management practice of scheduled removal of the aboveground vegetation prior to flowering will eliminate the possible transfer to pollen collectors (bees and wasps).

Direct consumers of the sap or liquid content of the plants vascular system (xylem and phloem) may be potentially contaminated. Sap suckers (aphids) feed directly on the transport stream as it comes from the roots and sites of storage. This material has a higher concentration of minerals, including $\mathrm{Ca}$ and $\mathrm{Sr}$, than vegetative tissue. The digestive exudates extruded from the aphids ("honeydew") may fall onto other surfaces such as lower leaves and the soil. Further, the honeydew itself may become a food for other insects such as ants and may be an additional source of contaminant transport.

Insects that may feed on contaminated plant tissues (leaves/stems) are directly exposed and may bioaccumulate the contaminant. In turn, birds that might penetrate into the compound and consume consume herbivorous insect larvae (such as moth caterpillars feeding on contaminated vegetation) might demonstrate off-site food-chain transfer (Johnson and Reeves 1995, Kozlov et al. 2000). In addition, if the adult insect is capable of flight, it may also facilitate long-distance off-site transport. A primary example of this may be the Orthoptera species (grasshoppers/locusts), which are present in the Columbia Basin during the summer. They are voracious consumers and are very mobile. We have shown (Ainsworth and Fellows 2007) that ${ }^{90} \mathrm{Sr}$ concentrations of $142 \mathrm{dpm}(64 \mathrm{pCi}) / \mathrm{g}$ dry wt can be found in the leaves of coyote willow grown in 100-N sediment. Laval Lepodoptera species such as soybean loopers have been reported to consume up to $0.5 \mathrm{~g}$ dry wt/day (fifth instar)/g dry wt of the animal (CarterWientjes et al. 2004, Barton-Browns and Raubenheimer 2003, Jolanta et al. 2002, Jost and Petrie 2002), while grasshoppers have been reported to do the same (Crawford et al. 1996). Assuming that the fifth instar stage lasts $\sim 7$ days (Trichilo and Mack 1989), the caterpillar (of $1 \mathrm{~g} \mathrm{wt}$ ) might consume $3.5 \mathrm{~g}$ of leaf tissue and retain all of the label (potentially $497 \mathrm{dpm}[225 \mathrm{pCi}] /$ insect). Actual dispersal of the western corn rootworm (Diabrotica virgifera) instars is limited often to less than 4.6 to $9.1 \mathrm{~m} /$ day (Spencer et al. 2003). This suggests that the larval instars may not be subject to off-site transfer, although if they retain a significant amount of the ${ }^{90} \mathrm{Sr}$, the adults could be another source of off-site transfer, as it has been shown that black cutworm adult moths can disperse as far as $1266 \mathrm{~km}$ (Showers et al. 1989).

A higher predator such as the red-winged blackbird (Agelaius phoeniceus) could be a significant concern if the larval instar retained all of the contaminant (which is unlikely) and was accessible, as the bird feeds exclusively on the contaminated insect. A red-winged blackbird weighs an average of $65 \mathrm{~g}$ (Beletsky 1996) and can eat 10 to $20 \mathrm{~g}$ in food (seed and insects)/day (Mason and Reidinger 1981). This would mean that the bird is potentially exposed to $20 \mathrm{~g} \times 497 \mathrm{dpm} / \mathrm{g}$ insect $=9490 \mathrm{dpm}(4518 \mathrm{pCi}) / \mathrm{day}$ and would be easily capable of transfer off of the Hanford Site. The determination of the validity of this worst-case scenario is therefore important to the application of this technology.

Several moth and aphid species are indigenous to the Hanford area and often restrict themselves to specific plant species. We have determined that these species will colonize the coyote willow and persist over the entire growing season; therefore, we employed them in our studies. For example, the giant willow aphid (Pterochlorus viminalis) was identified as an occasional pest in the Pacific Northwest 
National Laboratory (PNNL) greenhouses. In addition, many of these species may have restricted reproductive phases during the year. Of those species capable of several generations over the growing season and as generalists in their preferred food source, the oblique-banded leaf roller (OBLR;

Choristoneura roseceana [Harris]), a moth in the Tortidae family with a 30-40 day life cycle was chosen for its being amenable to culturing in the laboratory or greenhouse. Further, a colony is available at the U.S. Department of Agriculture's Agricultural Research Service (USDA-ARS) Yakima Research Station located in Wapato, Washington.

The primary objective of this project is to evaluate potential for off-site food chain transfer of ${ }^{90} \mathrm{Sr}$ from plants that may be growing in contaminated soil on the shoreline at 100-N Area on the Hanford Site. While larger herbivores can be excluded from the shrubs through engineering and procedural controls, the close proximity of the Columbia River limits the use of pesticides to control insects that feed on plant tissue during their life cycles. Further, insects are capable of transporting the contaminant for large distances before they may be subject to predation.

Potential pathways of contaminant transfer can occur in specific stages of the insect's life cycle including several stages post-hatching from their eggs. Also, different species of insects may have unique methods of plant tissue consumption that could affect their ability to carry the material off-site.

Therefore, specific objectives include the potential for food chain transfer: (a) in sucking insects, (b) the larval stages of Lepidoptera which may ingest large quantities, and (c) mobile adults who may spend long periods of time consuming the contaminated tissue. 


\subsection{Materials and Methods}

This chapter describes the materials used and the experimental procedures followed to ascertain the uptake and fate of ${ }^{90} \mathrm{Sr}$-contaminated plant tissue as it is consumed by insect herbivores.

\subsection{Sediment Selection and Activity Determination}

Sediments used for plant growth and insect experiments were obtained from 100-N boreholes taken around previously placed wells along the $100-\mathrm{N}$ shoreline. The soils were sieved to $<4 \mathrm{~mm}$ in size. The boreholes were from differing depths and locations; therefore, sample contaminant levels varied. For each experiment, several soil (sediment) samples were chosen, which were bulked and thoroughly mixed (Table 2.1). The percent moisture was determined after mixing to obtain a true dry wt. All subsequent measurements and data are reported on a g dry wt soil basis for the studies.

Table 2.1. Soils (sediments) Used for the Aphid and Moth Studies

\begin{tabular}{|c|c|c|c|c|}
\hline Study & Sample No. & Well ID No. & $\begin{array}{c}\text { Final Acid Extractable } \\
{ }_{90}^{90} \text { Activity } \\
(p C i / g \text { soil dry } w t)\end{array}$ & $\begin{array}{l}\text { Porewater Extractable } \\
{ }_{90}^{90} \mathrm{Sr} \text { Activity } \\
(p \text { Ci/mL soil porewater })\end{array}$ \\
\hline \multirow[t]{4}{*}{ Aphid } & C4954 & $\mathrm{n}=122$ & $191 \pm 4$ & $6.8 \pm 2$ \\
\hline & C5048 & $\mathrm{n}=142$ & & \\
\hline & C5049 & $n=143$ & & \\
\hline & C5052 & $n=146$ & & \\
\hline \multirow[t]{3}{*}{ Moth } & C5046 & $\mathrm{n}=140$ & $205 \pm 18$ & $13 \pm 3$ \\
\hline & $\mathrm{C} 5042$ & $n=136$ & & \\
\hline & C5051 & $\mathrm{n}=145$ & & \\
\hline Activity da & rages \pm S.D. & & & \\
\hline
\end{tabular}

Subsamples $(\mathrm{n}=5)$ were taken for the following: acid extractable, water extractable, and porewater activities of ${ }^{90} \mathrm{Sr}$. For the acid extraction (total ${ }^{90} \mathrm{Sr}$ in soil), five 1-g (dry wt) samples of the mixed sediment were combined with $5 \mathrm{~mL}$ of $8 \mathrm{~N} \mathrm{HNO}_{3}$, sonicated for $10 \mathrm{~min}$, and allowed to set at room temperature overnight. One-mL aliquots were taken from each and counted by liquid scintillation spectroscopy (Beckman LS6500, Beckman Coulter Inc., Fullerton, CA) with appropriate standards and quench and Yttrium-90 $\left({ }^{90} \mathrm{Y}\right)$ interaction corrected (Table 2.1). Water-soluble label was determined in the same manner by substituting distilled water for the acid. Soil porewater activity was determined in soil samples brought to full water capacity and allowed to sit undisturbed for $24 \mathrm{~h}$. Subsamples $(\mathrm{n}=5)$ of approximately $5 \mathrm{~g}$ were placed in disposable glass chromatography columns $(1 \times 10 \mathrm{~cm})$ that contained a frittered glass plug at the base. The columns were placed in centrifuge tubes $(50 \mathrm{~mL})$ and centrifuged at $1000 \times \mathrm{g}$ for $10 \mathrm{~min}$. The water extruded from the column into the tube was collected, a volume taken, and counted by liquid scintillation. All data were corrected for ${ }^{90} \mathrm{Y}$ interaction and expressed as $\mathrm{pCi} / \mathrm{mL}$ (Table 2.1). 


\subsection{Plant Culture}

We obtained and divided (for each study) coyote willow cuttings (1-m long; Wildlands, Inc., Richland, WA) that originated from trees growing along the Yakima River in Benton County. Twentyfive $\mathrm{cm}$ cuttings were employed for the aphid study and placed in $15-\mathrm{cm}$ diameter plastic pots containing $430 \mathrm{~g}$ (dry wt) mixed 100-N sediment. Larger plants with additional foliage were required for the moth study, so $75-\mathrm{cm}$ cuttings were placed into 20 -cm pots with $1500 \mathrm{~g}$ (dry wt) of mixed 100-N sediment (Table 2.1).

The proximal (closer to the trunk end) was dipped into a commercial rooting material (Rootone ${ }^{\circledR}$; Garden Tech Inc., Lexington, KY) and kept in distilled water for 14 days until roots and shoots were initiated from the stem. The plants were grown for 60 days in the growth chamber with the lower onethird of the pot immersed in distilled water at all times to simulate a river shoreline situation. Growing conditions included a $12 \mathrm{~h}$ photoperiod $(\sim 300 \mu$ Einsteins of photosynthetically active radiation at canopy level), and $20 / 16^{\circ} \mathrm{C}$ day/night temperature.

\subsection{Exposure Procedure}

\subsubsection{Aphids}

Coyote willow plants grown from rooted 20 -cm cuttings for 60 days in the $100-\mathrm{N}$ soil were placed into $30 \times 30 \times 60 \mathrm{~cm}$ aluminum cages screened with $100-\mu$ nylon mesh (Figure 2.1). The pot was separated from the shoot with Plexiglas ${ }^{\circledR}$ panels sealed to the stem with Apiezon ${ }^{\circledR}-\mathrm{Q}$ compound (M \& I Materials Ltd., Manchester, UK) to prevent insect migration and/or contamination from the sediment. The top of the cage was also Plexiglas to maximize light exposure. Cages were maintained in the growth chamber under the same conditions given above. The floor of the exposure chamber (the Plexiglas sheet) was lined with Parafilm ${ }^{\circledR}$ to facilitate honeydew collection. The plants were watered from outside the cage using plastic tubing placed into the sediment of the pot, which allowed the cage to remain closed over the duration of the exposure.

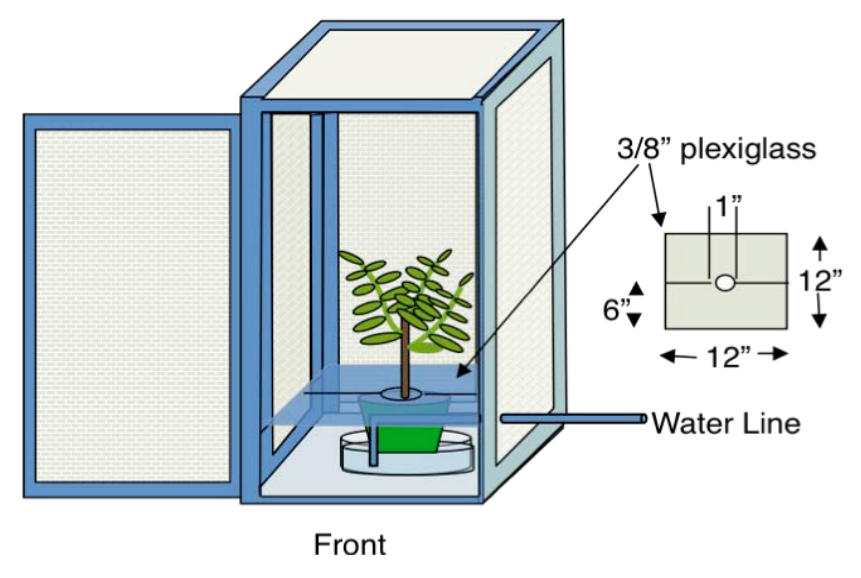

Figure 2.1. Diagram of Aphid Exposure Cage (plant shoot and insects are physically separated from ${ }^{90} \mathrm{Sr}$-sediment during exposure) 
Giant willow aphids were obtained from non-contaminated coyote willow plants growing in the PNNL greenhouse. Branches containing different developmental stages of the aphids from nymphs to winged adults were excised, transferred to the laboratory, and subsequently placed on the $100-\mathrm{N}$ sediment-grown plants within the cages to begin the exposure. The infested branches were left in place for $24 \mathrm{~h}$ to permit the transfer of aphids to the ${ }^{90} \mathrm{Sr}$-contaminated plants.

One group of plants $(n=3)$ was exposed to the aphids for 7 days, while a second group $(n=3)$ was exposed for 17 days. At the conclusion of the exposure, the plant cages were enclosed in a polyethylene bag containing dry ice for $45 \mathrm{~min}$ to anesthetize the insects. After the foliage was removed and separated from the original cutting, the leaves and stems were rinsed in ethanol solution $(10 \%[\mathrm{v} / \mathrm{v}] \mathrm{EtOH})$ to remove aphids and honeydew. The tissues were blotted dry, a fresh wt was taken, and the material was transferred to pre-tared vials. Honeydew was rinsed from the Parafilm lining the cage floor with the ethanol solution and combined with the foliage liquid. Aphids were filtered from the ethanol/honeydew mixture and placed in pre-tared vials. Plant tissues and aphids were then placed in a $80^{\circ} \mathrm{C}$ forced-air oven for $48 \mathrm{~h}$ to dry. The vials were allowed to cool in a desiccator, and a dry wt was taken. The ethanol/ honeydew was transferred to pre-tared vials, allowed to dry in a hood for $72 \mathrm{~h}$, and a dry wt was taken.

The dried plant tissues were then ground in a Wiley mill (Sargent-Welch, Philadelphia, PA) to a 20 -mesh size and stored in the vials at room temperature. Aliquots $(0.25$ to $0.5 \mathrm{~g}$, depending on sample size) were placed in $20-\mathrm{mL}$ scintillation vials, wetted with $1.0 \mathrm{~mL}$ of $8 \mathrm{~N} \mathrm{HNO}_{3}($ Optima Grade, Fisher Scientific, Pittsburgh, PA), and ashed at $500^{\circ} \mathrm{C}$ overnight in a muffle furnace. The ash was resuspended in $2 \mathrm{~mL}$ of concentrated $\mathrm{HNO}_{3}$ (Optima Grade), dried overnight at $100^{\circ} \mathrm{C}$, and ashed again at $500^{\circ} \mathrm{C}$ for $12 \mathrm{~h}$. One $\mathrm{mL}$ of $0.01 \mathrm{~N} \mathrm{HNO}_{3}$ was then added to the ash along with $15 \mathrm{~mL}$ of Ready-Safe ${ }^{\mathrm{TM}}$ scintillation cocktail (Beckman Coulter Inc., Fullerton, CA). The samples were counted with a Beckman LS6500 (Beckman Coulter) scintillation counter with appropriate quench curves and standards. All data were corrected for ${ }^{90} \mathrm{Y}$ interaction and expressed as $\mathrm{pCi} / \mathrm{g}$ dry wt.

Aphids were counted using a dissecting microscope from each plant sampled and then processed for

${ }^{90} \mathrm{Sr}$ content. The dried honeydew was resuspended in $20 \mathrm{~mL}$ of $10 \%(\mathrm{v} / \mathrm{v})$ ethanol, and $1.0 \mathrm{~mL}$ aliquots were transferred to scintillation vials. Scintillation cocktail was added and the vials counted with appropriate quench curves and standards. All data were corrected for ${ }^{90} \mathrm{Y}$ interaction and expressed as pCi/g dry wt.

Soil samples (2-3 g) were taken from each of the six plant pots and placed in disposable chromatography columns $(1 \times 10 \mathrm{~cm})$ containing a scintered glass frit. The columns were placed into $50-\mathrm{mL}$ conical centrifuge tubes, and the soil was centrifuged at $1200 \times \mathrm{g}$ for $20 \mathrm{~min}$. The soil porewater was collected from the tubes, combined, a volume taken, freeze-dried, reconstituted in $1.0 \mathrm{~mL}$ of $0.01 \mathrm{~N}$ $\mathrm{HNO}_{3}$, and counted by liquid scintillation. All data were corrected for ${ }^{90} \mathrm{Y}$ interaction and expressed as $\mathrm{pCi} / \mathrm{mL}$.

\subsubsection{Moths}

Coyote willow plants grown from rooted $76-\mathrm{cm}$ cuttings for 60 days in the $100-\mathrm{N}$ soil were placed into $30 \times 30 \times 120 \mathrm{~cm}$ aluminum cages screened with $100-\mu$ nylon mesh similar to that shown in Figure 2.1. The pot was again separated from the shoot with Plexiglas panels sealed to the stem with Apiezon-Q sealing compound (M \& I Materials) to prevent insect migration into and/or contamination 
from the sediment. The top of the cage consisted of Plexiglas to maximize light exposure. Cages were maintained in the growth chamber under the same conditions as for aphids. The plants were watered from outside the cage using plastic tubing placed into the sediment of the pot, allowing the cage to remain closed over the duration of the exposure.

Obtained from the USDA-ARS Yakima Agricultural Research Laboratory in Wapato, Washington, OBLR moth species were maintained in the laboratory at room temperature in 5-cm diameter plastic cups filled with nutrient media. The larvae were fed willow leaves for a minimum of $72 \mathrm{~h}$ prior to the exposure experiment to acclimate them to the new food source (Figure 2.2).

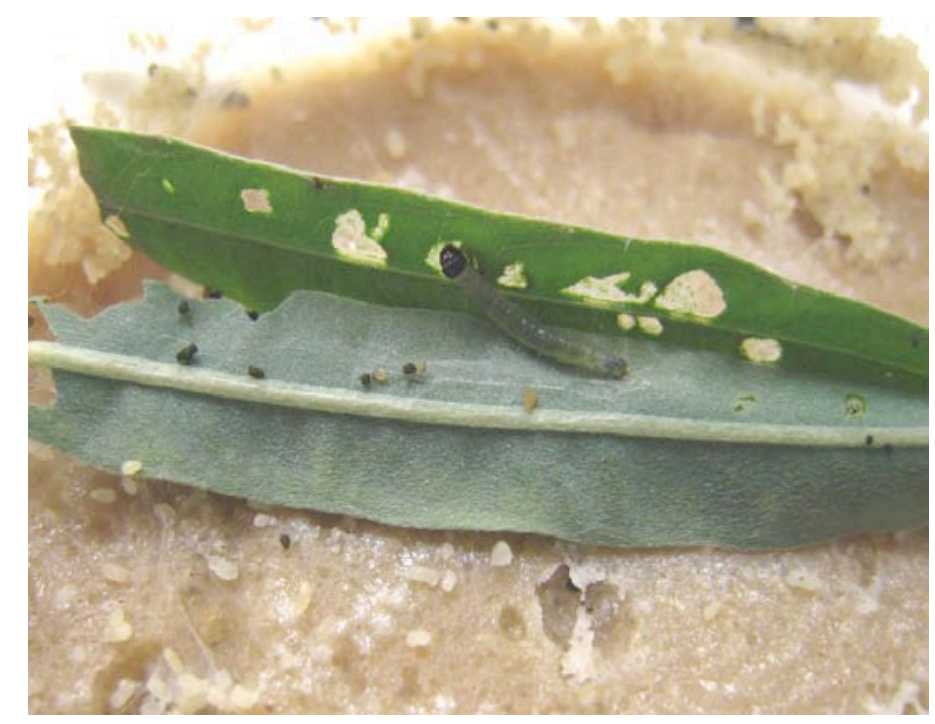

Figure 2.2. OBLR Feeding on Control Coyote Willow Leaf

Fifteen larvae (late fourth to fifth instar stage) were placed on each of the six plants in the insect cages (Figures 2.3 and 2.4) and were allowed to feed on the foliage for 10 days. At that time, one-third of the insects present on the plants were removed and transferred to pre-tared $20-\mathrm{mL}$ scintillation vials. A fresh wt was taken, and the insects frozen with powdered dry ice. The vials were then dried for $48 \mathrm{~h}$ in a forced-air oven at $110^{\circ} \mathrm{C}$ and transferred to a desiccator to cool, at which time a dry wt was taken. The dried material was wetted with $1.0 \mathrm{~mL}$ of $8 \mathrm{~N} \mathrm{HNO}_{3}$ (Optima Grade) and ashed at $500^{\circ} \mathrm{C}$ overnight in a muffle furnace and resuspended in $2 \mathrm{~mL}$ of concentrated $\mathrm{HNO}_{3}$ (Optima Grade), dried overnight at $100^{\circ} \mathrm{C}$, and ashed again at $500^{\circ} \mathrm{C}$ for $12 \mathrm{~h}$. One $\mathrm{mL}$ of $0.01 \mathrm{~N} \mathrm{HNO}_{3}$ was added to the ash along with 15 $\mathrm{mL}$ of Ready-Safe scintillation cocktail (Beckman Coulter). The samples were counted with a Beckman LS6500 (Beckman Coulter) scintillation counter with appropriate quench curves and standards. All data were corrected for ${ }^{90} \mathrm{Y}$ interaction and expressed as $\mathrm{pCi} / \mathrm{g}$ dry wt.

A second third of the insects were transferred to $50-\mathrm{mL}$ centrifuge tubes, where they were allowed to "clear" their digestive tracts on control plant tissue for $48 \mathrm{~h}$ (Figure 2.5). At that time, they were processed in the same manner as the first sampling.

The remaining third of the insects were allowed to pupate on the plants for 20 days. The emerged adults and their chrysali were collected and processed as described above, which would permit an estimation of the ${ }^{90} \mathrm{Sr}$ content of the fed larvae from the metamorphosed stage with the material still present in the digestive tract, the amount of the label retained in the body of the larvae (fourth to fifth 
instar), and the amount that may be retained in the adult moth. All three stages are considered prey by larger animals.

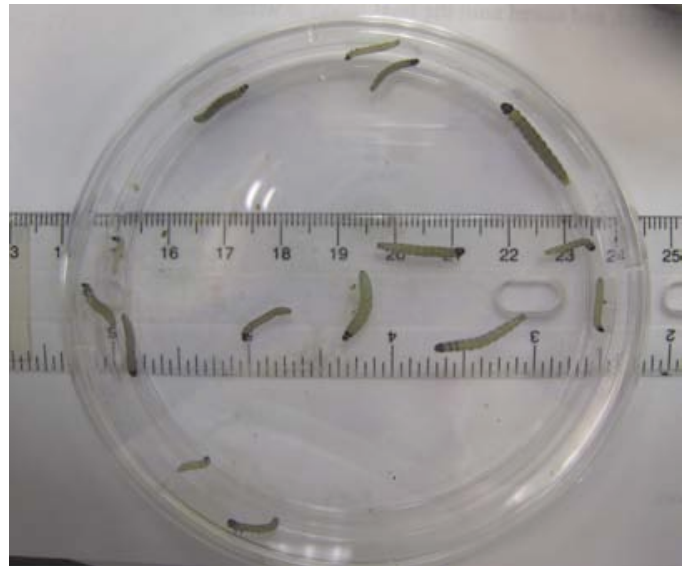

Figure 2.3. OBLR Larvae Prior to Placement on Coyote Willows

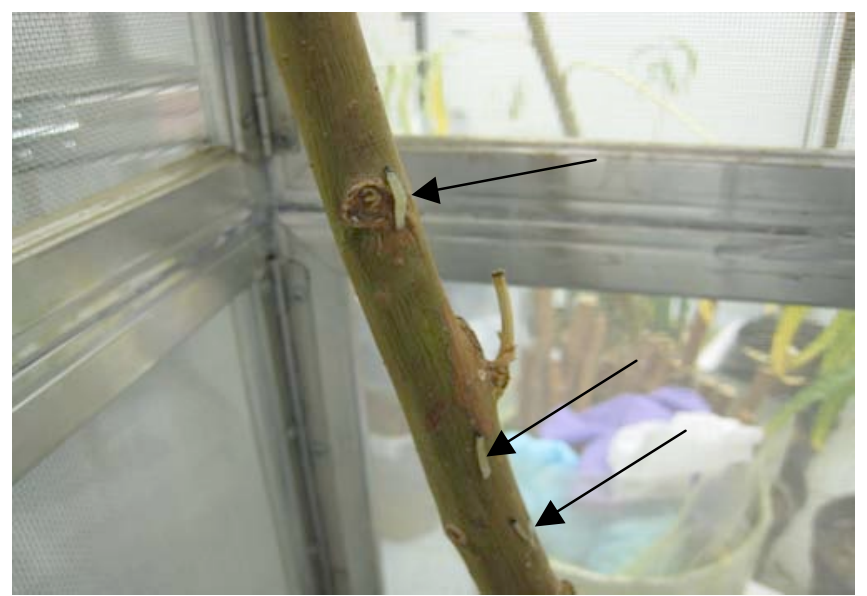

Figure 2.4. OBLR (arrows) Placed onto the Stem of Coyote Willow in the Exposure Cage Climbing Towards the Leaves 


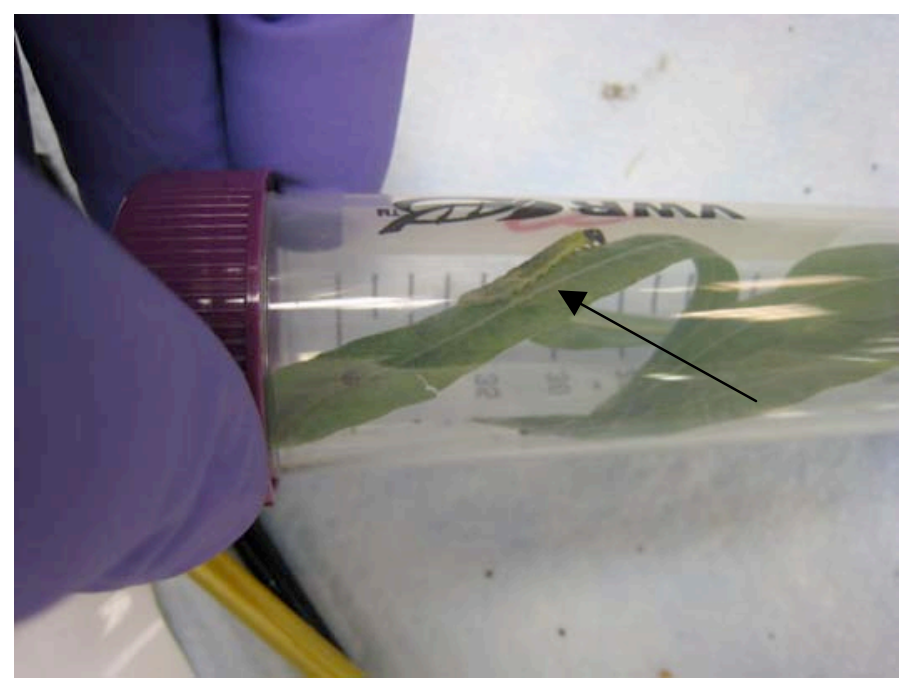

Figure 2.5. OBLR (arrow) Placed on Control Tissue to Clear its Digestive Tract Following the 10-Day Exposure

Following removal of the adults and chrysali, the plant was removed from the cage. The foliage (leaves and new stems) was removed from the original cutting, which was further sampled down to soil level. The tissues were transferred to pre-tared vials for a fresh wt determination. All plant tissues were dried for a minimum of $48 \mathrm{~h}$ at $110^{\circ} \mathrm{C}$ in a forced-air oven, after which a dry wt was determined. The dried plant tissues were then ground in a Wiley mill (Sargent-Welch) to a 20-mesh size and stored in the vials at room temperature. Aliquots ( 0.25 to $0.5 \mathrm{~g}$ depending on sample size) were placed in $20-\mathrm{mL}$ scintillation vials, wetted with $1.0 \mathrm{~mL}$ of $8 \mathrm{~N} \mathrm{HNO}_{3}$ (Optima Grade), and ashed at $500^{\circ} \mathrm{C}$ overnight in a muffle furnace. The ash was to be resuspended in $2 \mathrm{~mL}$ of concentrated $\mathrm{HNO}_{3}$ (Optima Grade), dried overnight at $100^{\circ} \mathrm{C}$, and ashed again at $500^{\circ} \mathrm{C}$ for $12 \mathrm{~h}$. One $\mathrm{mL}$ of $0.01 \mathrm{~N} \mathrm{HNO}_{3}$ was added to the ash along with $15 \mathrm{~mL}$ of Ready-Safe scintillation cocktail (Beckman Coulter). The samples were counted with a Beckman LS6500 (Beckman Coulter) scintillation counter with appropriate quench curves and standards. All data were corrected for ${ }^{90} \mathrm{Y}$ interaction and expressed as $\mathrm{pCi} / \mathrm{g}$ dry wt. 


\subsection{Results and Discussion}

The stem and foliage of Coyote willows growing along the 100-N Area Columbia River shoreline, and accumulating ${ }^{90} \mathrm{Sr}$, present both a source of nutrition for various natural herbivores and a potential pathway for the isotope to enter the riparian food chain. Resident and transitory insects may accumulate ${ }^{90} \mathrm{Sr}$ from the tissues of the Coyote willow by consuming the pollen, sap, and/or foliage. The following chapter addresses the results of laboratory studies of aphids and moths feeding on coyote willow plants grown in $100-\mathrm{N}{ }^{90} \mathrm{Sr}$-contaminated soil.

\subsection{Plant Phytoextraction}

The studies and the potential for phytoextraction application as a part of the treatment chain at the $100-\mathrm{N}$ shoreline are predicated on the ability of coyote willow to retrieve ${ }^{90} \mathrm{Sr}$ from the soil and move it to the shoot of the plant, where it can be harvested and removed from the site. Each of the experiments described is based on the use of actual 100-N sediment taken from the bank of the Columbia River below the 100-N reactor. The tissues to be harvested in this scenario are the new growth stems and leaves that will emerge each growing season; these are also the principle foodstuffs of the herbivorous insect species of this report. Data provided below will reveal that the ${ }^{90} \mathrm{Sr}$ is present in the tissues and therefore potentially available to these insects.

The physical size differences of the two insect species studied, aphids and moths, dictated that variably sized plants would be required to provide sufficient tissue for potential food over the exposure period. The soil ${ }^{90} \mathrm{Sr}$ activities for the two experiments are given in Table 3.1. It should be noted that following the mixing process, the acid-extractable specific activity ( $\mathrm{pCi}^{90} \mathrm{Sr} / \mathrm{g}$ dry wt of soil) used in both experiments is not statistically different. However, since there was more soil employed for the larger plants used for the moths, there was a greater initial amount of ${ }^{90} \mathrm{Sr}$ present at the start of the experiment (Table 3.1). The initial specific activity of the 100-N sediment in which the willow cuttings were grown was $217 \pm 4 \mathrm{pCi}{ }^{90} \mathrm{Sr} / \mathrm{g}$ dry wt, as determined by $\mathrm{HNO}_{3}$ extraction. At the end of 60 days, apparently through plant uptake, the pot sediment ${ }^{90} \mathrm{Sr}$ activity had decreased to $119 \pm 4 \mathrm{pCi} / \mathrm{g}$ dry wt, which was also determined by $\mathrm{HNO}_{3}$ extraction.

Table 3.1. Plant Height, Amount, and Activity of 100-N Sediment Used/Plant and the Soil (100-N Borehole Sediment) Acid Extractable ${ }^{90} \mathrm{Sr}$ Activity Before and After 60 Days of Plant Growth for the Aphid and Moth Experiments

\begin{tabular}{ccccc}
\hline Experiment & $\begin{array}{c}\text { Plant Height } \\
(\mathrm{cm})\end{array}$ & $\begin{array}{c}\text { Soil Wt/Pot } \\
(g d r y w t)\end{array}$ & $\begin{array}{c}\text { Initial Acid Extractable }{ }^{90} \mathrm{Sr} \\
\text { Activity } \\
(p C i / g \text { soil } d r y w t)\end{array}$ & $\begin{array}{c}\text { Initial Total Activity } \\
\text { Present/Pot } \\
(p C i)\end{array}$ \\
\hline Aphids & 20 & 430 & $217 \pm 4$ & $93330 \pm 1861$ \\
Moths & 76 & 1500 & $205 \pm 18$ & $307841 \pm 27421$ \\
\hline Activities are averages given as $\mathrm{pCi}{ }^{90} \mathrm{Sr}$ or $\mathrm{pCi}{ }^{90} \mathrm{Sr} / \mathrm{g}$ dry wt of soil \pm S.D. $(\mathrm{n}=5)$ & \\
\hline
\end{tabular}

Where Table 3.1 indicates a diminished amount of ${ }^{90} \mathrm{Sr}$ in the $100-\mathrm{N}$ soil over time, Table 3.2 shows that the plants did extract the ${ }^{90} \mathrm{Sr}$ from the soil and transport it to the new growth foliage. The taller moth plants growing in the larger pots contained almost four times the activity of those smaller aphid plants, 
both on a total amount and a higher specific activity on a dry wt basis (Table 3.2). Within the new growth foliage, more ${ }^{90} \mathrm{Sr}$ was partitioned to the leaves ( $\left.\sim 68 \%\right)$ than to the new growth stems $(\sim 32 \%$; Table 3.2$)$. These results are seen in previous studies (Ainsworth and Fellows 2007) for willows grown both in hydroponics and 100-N soil.

Table 3.2. Willow Leaf-Specific Activity ( $\mathrm{pCi}{ }^{90} \mathrm{Sr} / \mathrm{g}$ dry wt), the Total Recovered ${ }^{90} \mathrm{Sr}$ in the New Growth Stems and Leaves on Each Plant, and the Percent of Total Recovered ${ }^{90} \mathrm{Sr}$ activity Distribution Between New Growth Leaves and Stems

\begin{tabular}{ccccc}
\hline & & $\begin{array}{c}\text { Total }{ }^{90} \text { Sr Activity } \\
\text { in New Growth } \\
\text { Tissue (Leaves } \\
\text { and Stems }) \\
(p C i)\end{array}$ & $\begin{array}{c}\text { Percent Total } \\
\text { Activity in New } \\
\text { Growth Leaves } \\
(\%)\end{array}$ & $\begin{array}{c}\text { Percent Total } \\
\text { Activity in New } \\
\text { Growth Stems } \\
(\%)\end{array}$ \\
\hline Aphids & $437 \pm 89$ & $1232 \pm 342$ & $69 \pm 5$ & $31 \pm 5$ \\
Moths & $1653 \pm 605$ & $5490 \pm 2280$ & $67 \pm 6$ & $33 \pm 6$ \\
\hline
\end{tabular}

Data are averages \pm S.D. $(n=15)$

Recently, Sysoeva et al. (2005) reported that the ${ }^{90} \mathrm{Sr}$ plant uptake correlates to the exchangeable $\mathrm{Ca}^{+2}$ content of the soil porewater (also known as the soil solution). Both Casadesus et al. (2008) and Ainsworth and Fellows (2007) noted that selectivity coefficients of 1.0 and correlation coefficients of 0.99 between $\mathrm{Ca}$ and $\mathrm{Sr}$ plant uptake in hydroponic experiments. Additionally, White (2001) found that the $\mathrm{Sr}$ and $\mathrm{Ca}$ apoplastic (outside of the cell membrane) fluxes for transport to the shoot of plants from the roots are nearly identical. These reports indicate that it is the concentration of the ion present in the soil solution (porewater) and not the total concentration present in the soil that determines uptake or bioavailabilty to the root/plant system.

The ratio of plant contaminant uptake (as opposed to the soil contaminant concentration) on a dry wt basis is referred to as the concentration ratio (CR) or transfer factor. In plants, CRs for ${ }^{90} \mathrm{Sr}$ vary widely depending on plant species, rooting medium (soil pH, CEC, organic matter content, clay content, etc.; Ainsworth and Fellows 2007, Chojnackaet et al. 2005, Ehlken and Kirchner 2002) or microbial (Kuffner et al. 2008) composition of the rhizosphere. The more appropriate calculation of the CR would employ the concentration in the porewater on a per-mL $(\mathrm{g})$ basis. While not the optimal method of obtaining direct samples of porewater (Angelidis 1997, Gollany et al. 1997, Lorenz et al. 1994), centrifugation is simpler and more rapid than compression or extraction with acrylamide gels (Jouvre et al. 1999). Therefore, centrifugation was the method of choice for soil porewater collection in these studies.

The soil porewater or soil solution activity at the conclusion of the experiment was determined by bulk soil centrifugation of the 100-N soil at field capacity (sufficient water to fill most of the soil pores but not enough to drain from gravity). For the aphid experiment, results were $7 \pm 2 \mathrm{pCi}{ }^{90} \mathrm{Sr} / \mathrm{mL}$, while for the moth (using soil from different boreholes), the yield was $13 \pm 2 \mathrm{pCi}{ }^{90} \mathrm{Sr} / \mathrm{mL}$ (Table 3.3). The leaf tissue was chosen as the plant component because it is tissue on which both the aphids and moths feed. The soil porewater ${ }^{90} \mathrm{Sr}$ content is the actual activity present in the rhizosphere of the plant root in contact with the root and available for plant uptake. The plant CR defined as $\left[\left(\mathrm{pCi}^{90} \mathrm{Sr} / \mathrm{g}\right.\right.$ dry wt of new growth tissue $) /\left(\mathrm{pCi}^{90} \mathrm{Sr} / \mathrm{g}\right.$ soil porewater $\left.)\right]$ was 61 for aphids and 94 for moths. These results demonstrate that 
the willows were capable of accumulating ${ }^{90} \mathrm{Sr}$ at high enough concentrations to make phytoextraction a potential methodology for riparian zone remediation and a potential source for off-site transfer.

Table 3.3. Soil Acid Extractable and Leaf ${ }^{90} \mathrm{Sr}$ Specific Activity (pCi/g Dry Wt) and ${ }^{90} \mathrm{Sr}$ Porewater Activity (pCi/mL) Used to Calculate the Willow Concentration Ratios

\begin{tabular}{|c|c|c|c|c|c|}
\hline Experiment & $\begin{array}{c}\text { Initial Acid } \\
\text { Extractable }{ }^{90} \mathrm{Sr} \\
\text { Activity } \\
(p C i / g \text { soil dry wt) }\end{array}$ & $\begin{array}{c}\text { Soil } \\
\text { Porewater } \\
\text { Activity } \\
(p C i \text { i } 90 \mathrm{Sr} / \mathrm{mL})\end{array}$ & $\begin{array}{l}\text { New Growth } \\
\text { Leaf Specific } \\
\text { Activity } \\
\left(p C i{ }^{90} S r / g\right. \\
d r y w t)\end{array}$ & $\begin{array}{c}\text { Acid Extractable } \\
\text { Concentration Ratio } \\
(p C i / g \text { new growth } \\
\text { dry wt } / p C i{ }^{90} \mathrm{Sr} / \mathrm{g} d r y \\
\text { wt soil })\end{array}$ & $\begin{array}{c}\text { Soil Porewater } \\
\text { Concentration Ratio } \\
\text { (pCi/g new growth } \\
\text { dry wt } / p C i{ }^{90} \mathrm{Sr} / \mathrm{mL} \\
\text { porewater) }\end{array}$ \\
\hline Aphids & $217 \pm 4$ & $7 \pm 2$ & $437 \pm 89$ & 2.01 & 61 \\
\hline Moths & $205 \pm 18$ & $13 \pm 2$ & $1653 \pm 605$ & 8.06 & 94 \\
\hline Data a & $e s \pm$ S.D. $(n=15)$ & & & & \\
\hline
\end{tabular}

\subsection{Aphid Feeding Study}

Aphids are small insects that insert their mouthparts (stylets) into the vascular tissue of plants where they feed on the cell sap, specifically the contents of the phloem sieve-elements (Dixon 1975). The sap contained within the sieve-element is under high pressure (1.5 to $3.0 \mathrm{mPa})$, and once pierced by the stylet of the feeding aphid the sap has been shown to exude at a volume of up to $6 \mu \mathrm{L} / \mathrm{h}$ from a single cut stylet (Peel 1975). This large a volume presents a digestive problem for the insect, yet the aphid can selectively sample the material for its nutritional needs (Dixon 1975), modify the contents of the sap within its digestive track (Douglas 2006), and the sap is exuded from its body as a thick liquid referred to as honeydew. While not exhibiting significant transport through the phloem of higher plants, $\mathrm{Ca}^{+2}$ (and therefore Sr; Zimmermann 1969) is found in $\mathrm{mg} / \mathrm{ml}$ concentrations in aphid honeydew (Zeigler 1975, Fisher 1983). The experiment was thus designed to determine if ${ }^{90} \mathrm{Sr}$ present in willow stems and leaves following phytoextraction from the $100-\mathrm{N}$ soil, could be accumulated by aphids feeding on the plant, lost to the environment in the exuded honeydew, or both.

Aphid infestation of the test plants was successful, as seen in Figures 3.1 and 3.2. The aphids were frequently seen to cluster at nodes where leaves or new stems branched from the main stem. These are sites where there are larger vascular bundles and opportunities for feeding (Esau 1965). In order to assess if variations in the amount of contaminant transfer to the environment might occur with longer exposure, plants were sampled at 7 and 17 days following transfer of the greenhouse aphid populations. 


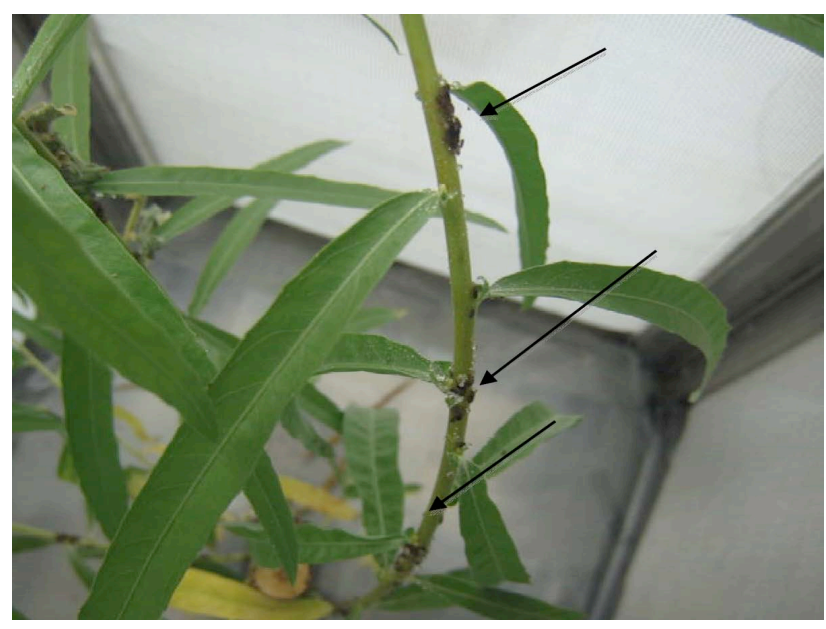

Figure 3.1. Aphid Colonization (arrows) of Willow Stems 3 Days After the Start of the Exposure

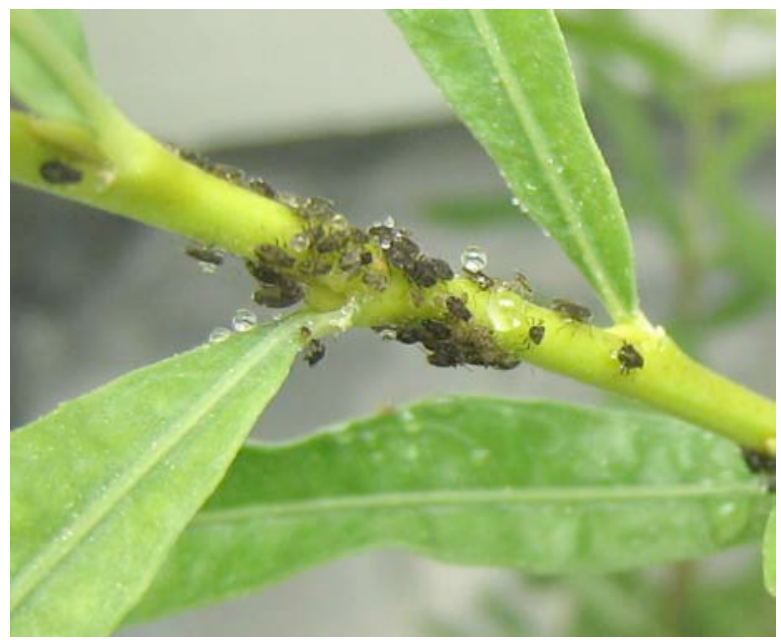

Figure 3.2. Image of Aphids and Their Excretory Honeydew on Coyote Willows Grown in ${ }^{90} \mathrm{Sr}-$ Contaminated 100-N Sediment

Based on the average wt for the aphids, the numbers collected on a per-plant basis were approximately $2512 \pm 1067$ for the 7-day exposed plants and $1851 \pm 1172$ for the 17 -day plants (Table 3.4). The variations are not significant but simply reflect the fact that we were unable to control accurately the numbers of the insects that transferred from the infested greenhouse tissue to the experimental plants within the growth chamber.

Table 3.4. Dry Wt of Aphid Population Collected From Exposed Plants and Estimation of Total Aphid Number (All Life Stages) on the Plants After 7- and 17-Days Exposure

\begin{tabular}{|c|c|c|c|}
\hline Plant Number & Days Exposed & $\begin{array}{c}\text { Total Aphid Dry Wt/Plant at } \\
\text { Conclusion of Exposure } \\
\text { (g) }\end{array}$ & $\begin{array}{c}\text { Estimated }^{(\mathrm{a})} \text { Number of } \\
\text { Aphids/Plant at } \\
\text { conclusion of Exposure } \\
\text { (No.) }\end{array}$ \\
\hline 1 & 7 & 0.0696 & 3247 \\
\hline 2 & 7 & 0.0643 & 3000 \\
\hline
\end{tabular}




\begin{tabular}{cccc}
\hline 3 & 7 & 0.0276 & 1288 \\
& Avg & 0.0538 & 2512 \\
& SD & 0.0229 & 1067 \\
& & & \\
4 & 17 & 0.0683 & 3187 \\
5 & 17 & 0.0213 & 994 \\
6 & 17 & 0.0294 & 1372 \\
& Avg & 0.04675 & 1851 \\
& SD & 0.02285 & 1172 \\
\hline
\end{tabular}

(a) Based on average wt of $2.55 \times 10^{-5} \pm 1.02 \times 10^{-5} \mathrm{~g}$ /aphid from 3600 counted insects (all life stages).

Although present at very low levels, there was ${ }^{90} \mathrm{Sr}$ uptake by the aphids feeding on the willows (Table 3.5). The average total dry wt of the aphid infestation for all of the plants was $0.0468 \pm 0.0229 \mathrm{~g}$ with a ${ }^{90} \mathrm{Sr}$ activity of $1.7 \pm 0.8 \mathrm{pCi}$. At a high infestation level within a proposed plot at $100-\mathrm{N}$ of 1000 trees ( $1-\mathrm{m}$ centers), this would give a total area of 0.1 hectare, an aphid dry wt of $4.64 \mathrm{~g}$ and a ${ }^{90} \mathrm{Sr}$ activity of $1700 \mathrm{pCi}$ distributed over the $1000 \mathrm{~m}^{2}\left(1.7 \mathrm{pCi} / \mathrm{m}^{2}\right)$, an insignificant amount.

Table 3.5. Specific Activity (pCi ${ }^{90} \mathrm{Sr} / \mathrm{g}$ dry wt) and Percent Distribution of Total Recovered Activity of ${ }^{90} \mathrm{Sr}$ in Tissue (leaf and stem), Aphids, and Aphid Honeydew Following Aphid Exposure to Plants Grown in ${ }^{90} \mathrm{Sr}-$ Contaminated 100-N Sediment

\begin{tabular}{|c|c|c|c|c|c|c|c|}
\hline \multirow[b]{2}{*}{$\begin{array}{l}\text { Plant } \\
\text { No. }{ }^{(a)}\end{array}$} & \multicolumn{4}{|c|}{${ }^{90} \mathrm{Sr}$ Activity $\left(p C i{ }^{90} \mathrm{Sr}\right)$} & \multicolumn{3}{|c|}{ Percent of Plant-Extracted ${ }^{90} \mathrm{Sr}(\%)$} \\
\hline & $\begin{array}{l}\text { Collected } \\
\text { Honeydew }\end{array}$ & $\begin{array}{c}\text { Collected } \\
\text { Aphids }\end{array}$ & $\begin{array}{c}\text { New } \\
\text { Growth } \\
\text { Stem and } \\
\text { Leaves }\end{array}$ & Sum/Plant & Honeydew & Aphids & $\begin{array}{c}\text { Stem and } \\
\text { Leaves }\end{array}$ \\
\hline 1 & 14.3 & 1.9 & 1291.9 & 1308.1 & 1.09 & 0.15 & 98.76 \\
\hline 3 & 9.1 & 0.7 & 1032.1 & 1041.8 & 0.87 & 0.06 & 99.06 \\
\hline 4 & 24.5 & 2.9 & 1733.8 & 1761.2 & 1.39 & 0.17 & 98.44 \\
\hline 5 & 12.7 & 1.9 & 818.5 & 833.1 & 1.53 & 0.23 & 98.25 \\
\hline 6 & 12.7 & 1.7 & 1287.4 & 1301.8 & 0.98 & 0.13 & 98.89 \\
\hline Avg & 14.7 & 1.8 & 1232.7 & 1249.2 & 1.17 & 0.15 & 98.68 \\
\hline SD & 5.8 & 0.8 & 342.6 & 348.1 & 0.28 & 0.06 & 0.33 \\
\hline
\end{tabular}

(a) Portions of plant \#2 were lost in sample preparation and are not included in this table.

The specific aphid activity (pCi ${ }^{90} \mathrm{Sr} / \mathrm{g}$ dry wt) increased from $22 \pm 7 \mathrm{pCi}{ }^{90} \mathrm{Sr} / \mathrm{g}$ dry wt after 7 days to $63 \pm 23 \mathrm{pCi}{ }^{90} \mathrm{Sr} / \mathrm{g}$ dry wt at 17 days; therefore, the average aphid activity was only $0.15 \pm 0.06 \%$ of the total activity extracted from the soil by the plant (Table 3.5).

The total new growth tissue (stems and leaves) that emerged from the original cutting averaged $2.98 \pm$ $0.68 \mathrm{~g}$ dry wt after 60 days of growth. Average tissue ${ }^{90} \mathrm{Sr}$ specific activity ( $\mathrm{pCi}^{90} \mathrm{Sr} / \mathrm{g}$ dry wt) extracted by the plant from the $100-\mathrm{N}$ sediment over the 60 -day growth period was $415 \pm 77 \mathrm{pCi}{ }^{90} \mathrm{Sr} / \mathrm{g}$ dry wt. 
Individually, the new growth stem specific activity was $364 \pm 76 \mathrm{pCi}{ }^{90} \mathrm{Sr} / \mathrm{g}$ dry wt and the leaf specific activity was $437 \pm 89 \mathrm{pCi}{ }^{90} \mathrm{Sr} / \mathrm{g}$ dry wt. Of the total phytoextracted ${ }^{90} \mathrm{Sr}$ from the $100-\mathrm{N}$ sediment during this experiment and recovered from the shoot, aphids, and honeydew, $98.7 \pm 0.3 \%$ was found in the plant itself (Table 3.5). Approximately $67 \%$ of the ${ }^{90} \mathrm{Sr}$ in the new growth of the plant was contained in the leaves, while the stems contained over $31 \%$.

Total average production of honeydew collected from the plant and cage surfaces averaged $0.9 \pm 0.1$ $\mathrm{g}$ after 7 days and $1.6 \pm 0.3 \mathrm{~g}$ after 17 days. The honeydew-specific activity was not significantly different over time, with $23.5 \pm 18 \mathrm{pCi}{ }^{90} \mathrm{Sr} / \mathrm{g}$ dry wt at 7 days and $11.0 \pm 5.6 \mathrm{pCi}{ }^{90} \mathrm{Sr} / \mathrm{g}$ dry wt at 17 days. The total ${ }^{90} \mathrm{Sr}$ activity in the honeydew consistently averaged $1.17 \pm 0.28 \%$ of that ${ }^{90} \mathrm{Sr}$ extracted from the sediment by the plant (Table 3.5).

That portion of the total ${ }^{90} \mathrm{Sr}$ extracted from the soil by the plants available to the aphids was currently in transit within the plant's phloem sap. As a nutritional analog to calcium in the plant, $\mathrm{Sr}$ would be partitioned within the plant in the same manner. Although not major components of the phloem sap (Zimmerman 1969), $\mathrm{Ca}$ and $\mathrm{Sr}$ are apparently present in the aphids in small amounts. The probable sources for the $\mathrm{Ca}^{+2}$ would come from outside of the phloem from both exchange with the xylem (generally in close proximity) as well as tissue storage along the path of the phloem so that both newly assimilated $\mathrm{Sr}$ from the roots as well as stored $\mathrm{Sr}$ from the tissue could contribute to the content of the phloem sap (Will and Van Bel 2006, Van Bel 1990).

Under an osmotically driven pressure head, the sap is forcefully passed into the aphid's digestive system when punctured by the insect's stylet. The result of this is a rapid passage through the aphid, meaning that the insect can extract only a small portion of the phloem $\mathrm{Sr}$ for itself; the rest is exuded as "honeydew" from the aphid's body. The observed ${ }^{90} \mathrm{Sr}$ activity from the exuded aphid honeydew from the plants grown in ${ }^{90} \mathrm{Sr}$-contaminated $100-\mathrm{N}$ sediment is given in Table 3.5. At the heavy level of aphid infestation applied to the plants, there was an average of $0.1 \pm 0.02 \mathrm{~g}$ dry wt of honeydew deposited on the aphids (Figure 3.2), plant surfaces, and floor of the exposure cages/day. Also, on a daily basis this total exudate contained $1.3 \pm 0.5 \mathrm{pCi}$ of ${ }^{90} \mathrm{Sr}$. In a worst-case scenario over an entire 213-day growing season (March 15-October 15), this could total an estimated $268 \pm 115 \mathrm{pCi}$ of ${ }^{90} \mathrm{Sr} /$ infected plant that would be distributed over an area of soil/shoreline of from one to several $\mathrm{m}^{2}$ and would be below detection levels. To illustrate that this would not be a significant source of contamination, some rough calculations on an extreme case were performed using data shown in Table 3.6:

1. The current plan is to place the trees on a grid along the shoreline at 110-N with 1-m spacing, which provides a $1-\mathrm{m}^{2}$ area/tree.

2. Given a tree with a size and leaf area 10 times that used in this experiment and with a corresponding 10 times infestation of aphids and stipulating that all honeydew washed off the plant into the soil, the resulting deposition of ${ }^{90} \mathrm{Sr}$ to the shoreline sediment would be $\sim 2700 \mathrm{pCi} /$ growing season based on our experimental results.

3. Taking a possible soil bulk density of $1.5 \mathrm{~g} / \mathrm{cm}^{3}$ (Hanford soil ranges from 1 to $2.5+$ based on location), the shoreline bulk density would be higher because of the cobble.

4. Using the $1 \mathrm{~m}^{2}$ to a depth of $15 \mathrm{~cm}$ (a standard 6 in for agriculture), we have $15 \times 100 \times 100 \mathrm{~cm}$ or $150,000 \mathrm{~cm}^{3}$ of possible area below the plant. 
5. The wt of the soil would therefore be $\sim 225,000 \mathrm{~g}(\sim 225 \mathrm{~kg})$ and if the activity of the area is $2700 \mathrm{pCi}$, then $2700 / 225,000$ would give $0.012 \mathrm{pCi} / \mathrm{g}$, below detection in a soil profile that ranges $100-300$ $\mathrm{pCi} / \mathrm{g}$.

6. The potential rise and fall of the river or any precipitation would drive the activity deeper into the soil profile, thus lowering the activity possibly derived from the honeydew.

Table 3.6. Observed Amounts ( $\mathrm{g}$ ) and Activities ( $\mathrm{pCi}{ }^{90} \mathrm{Sr} / \mathrm{g}$ dry wt) of Aphid Honeydew Collected from Plants Grown in ${ }^{90} \mathrm{Sr}$-Contaminated $100-\mathrm{N}$ Sediment and Infested with Aphids

\begin{tabular}{|c|c|c|c|c|c|c|}
\hline $\begin{array}{l}\text { Plant } \\
\text { No.(a) }\end{array}$ & $\begin{array}{l}\text { Days of } \\
\text { Honeydew } \\
\text { Exudation }\end{array}$ & $\begin{array}{l}\text { Tot Dry Wt } \\
\text { of } \\
\text { Honeydew/ } \\
\text { Plant } \\
\text { (g) }\end{array}$ & $\begin{array}{l}\text { Honeydew } \\
\text { Dry Wt/Day/ } \\
\text { Plant } \\
\text { (g) }\end{array}$ & $\begin{array}{c}\text { Total }{ }^{90} \mathrm{Sr} \\
\text { Recovered in } \\
\text { Honeydew/Plant } \\
\quad(p C i)\end{array}$ & $\begin{array}{l}\text { Activity of }{ }^{90} \mathrm{Sr} \\
\text { Honeydew } \\
\text { Produced/Day/ } \\
\text { Plant } \\
(p C i)\end{array}$ & $\begin{array}{c}\text { Projected Total }{ }^{90} \mathrm{Sr} \\
\text { Release/ } \\
\text { Plant Over } \\
\text { Growing Season } \\
\text { (Mar 15-Oct 15) or } \\
\text { 213 Days } \\
(p C i)\end{array}$ \\
\hline 1 & 7 & 0.906 & 0.129 & 14.3 & 2.0 & 435.7 \\
\hline 3 & 7 & 0.869 & 0.124 & 9.1 & 1.3 & 276.6 \\
\hline 4 & 17 & 1.4109 & 0.083 & 24.5 & 1.4 & 307.5 \\
\hline 5 & 17 & 1.4356 & 0.084 & 12.7 & 0.7 & 159.5 \\
\hline \multirow[t]{3}{*}{6} & 17 & 1.8655 & 0.110 & 12.7 & 0.7 & 159.5 \\
\hline & & Avg & 0.106 & 14.7 & 1.3 & 267.8 \\
\hline & & SD & 0.022 & 5.8 & 0.5 & 115.4 \\
\hline
\end{tabular}

Data are expressed as a potential daily amount of ${ }^{90} \mathrm{Sr}$-contaminated honeydew on a daily and projected seasonal basis.

(a) Portions of plant \#2 were lost in sample preparation and are not included in this table.

\subsection{Moth Feeding Study}

This study addressed the potential for food chain transfer from willow through the larvae of herbivorous insects. Several moth species are indigenous to the Hanford area, and their larval (caterpillar) stages may be voracious consumers of foliage. Further, many of these species may have several generations over the growing season. The species chosen was OBLR, a moth in the Tortidae family.

In the field, the OBLR over-winter as larvae in a hibernaculum. They emerge as larvae during the spring usually in late May or early June. While feeding, they often protect themselves from predators such as birds by rolling up the leaf around them while they eat. Within 20 days, the larvae will pupate for 10-12 days, after which the OBLR emerge as adults. The adult moth generation can feed on fruit and leaves (not necessarily willow) and lay eggs (late August-September) that become the overwintering larvae.

As given in Table 3.1, the total activity present in the pots of these willows averaged $\sim 307,000 \mathrm{pCi}$. Analyzing the entire shoot (new growth and original stem portion), it was found that the plants phytoextracted an average of $29544 \pm 10177 \mathrm{pCi}$ from the pots over the 60-day growth period, meaning that the plant accumulated $9.8 \pm 4.0 \%$ of the original $100-\mathrm{N}{ }^{90} \mathrm{Sr}$ contaminant in 60 days. As shown in 
Figure 3.3, the leaves of the plants contained an average of $3750 \pm 1800 \mathrm{pCi}$, which was the activity available to the moths as they fed (Figure 3.4) on the tissue.

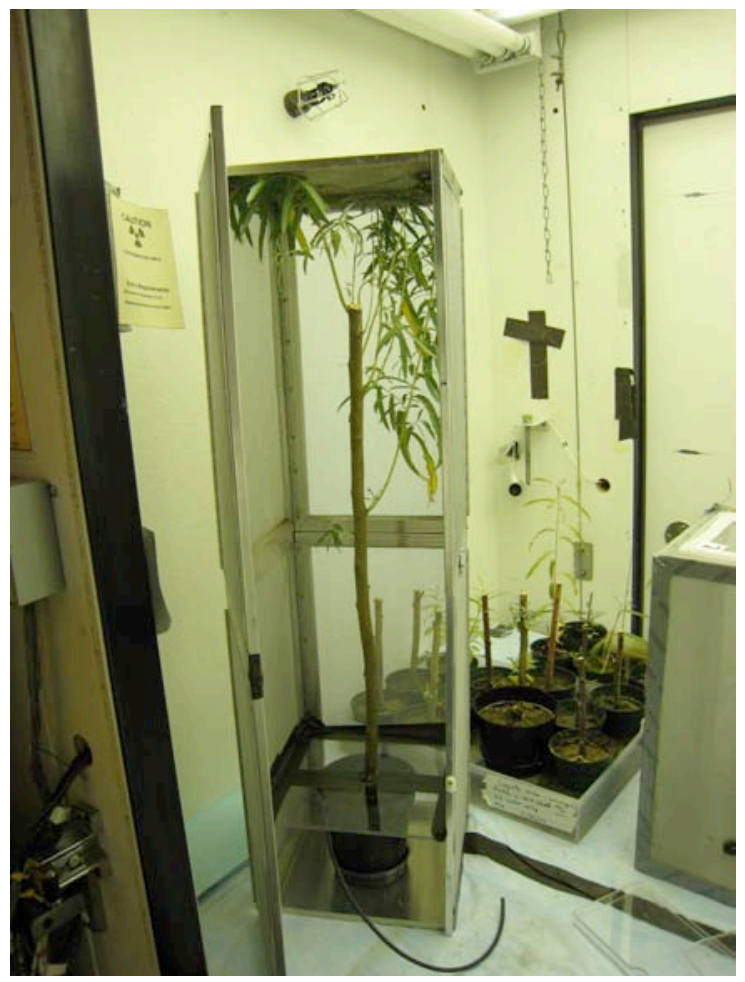

Figure 3.3. Exposure Chamber and One of Six Plants Used in Moth Experiment

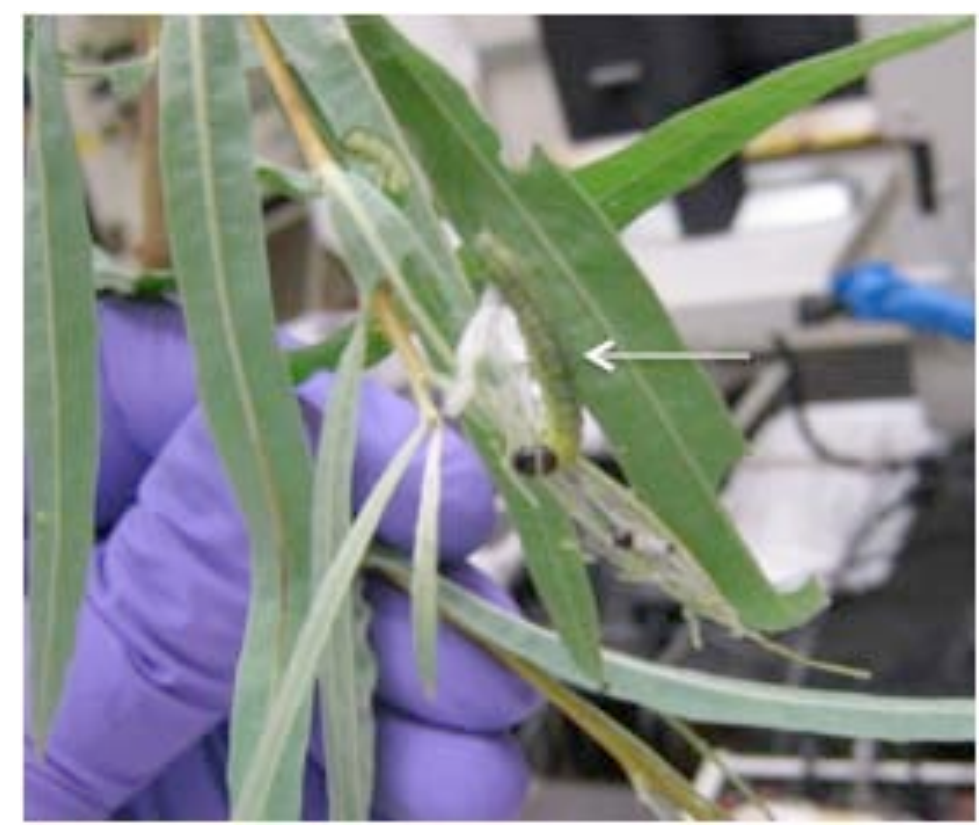

Figure 3.4. OBLR (arrow) on ${ }^{90} \mathrm{Sr}-$ Grown Coyote Willow After 10 Days of Exposure 
The feeding scenario was set at 10 days to provide sufficient time for the larvae to pass through the latter instar stages and approach the pupation period to provide maximum exposure to the contaminated foliage. The ${ }^{90} \mathrm{Sr}$ activity of the larvae at this point on a fresh and dry wt basis is given in Table 3.7. The ${ }^{90} \mathrm{Sr}$ activity of the individual larvae is very low $(1.4 \mathrm{pCi})$ but on fresh or dry wt, the level rises to 32 or $177 \mathrm{pCi} / \mathrm{g}$, respectively (Table 3.7 ).

Table 3.7. Strontium-90 Activity in pCi and Fresh and Dry Wt of OBLR Larvae at the Time of Harvest from the Contaminated Plants (uncleared) Following a 48-H Exposure to Control Leaves (cleared), the Empty Chrysalis, as Adults, and the Feces Produced by the Larvae During Exposure

\begin{tabular}{|c|c|c|c|c|c|}
\hline Sample & $\begin{array}{c}\text { Individual Larvae } \\
\text { at Harvest } \\
\left(p C i^{90} S r\right)\end{array}$ & $\begin{array}{l}\text { Individual } \\
\text { Fresh Wt } \\
\text { (g) }\end{array}$ & $\begin{array}{c}\mathrm{g} \text { Fresh Wt } \\
\left(p C i^{90} S r\right)\end{array}$ & $\begin{array}{c}\text { Individual } \\
\text { Dry Wt } \\
(g)\end{array}$ & $\begin{array}{l}\text { g Dry } \mathrm{Wt} \\
\left(p C i{ }^{90} \mathrm{Sr}\right)\end{array}$ \\
\hline Uncleared Larve & $1.4 \pm 1.0$ & $0.0484 \pm 0.0157$ & $32 \pm 30$ & $0.0087 \pm 0.003$ & $177 \pm 155$ \\
\hline Cleared Larvae & $\mathrm{BD}^{(\mathrm{a})}$ & $0.0345 \pm 0.0238$ & $\mathrm{BD}^{1}$ & $\begin{array}{c}0.0095 \pm \\
0.0027\end{array}$ & $\mathrm{BD}^{(\mathrm{a})}$ \\
\hline Chrysalis & $\mathrm{BD}^{(\mathrm{a})}$ & $0.0075 \pm 0.0063$ & $\mathrm{BD}^{1}$ & $\begin{array}{c}0.0032 \pm \\
0.0018\end{array}$ & $\mathrm{BD}^{(\mathrm{a})}$ \\
\hline Adult & $\mathrm{BD}^{(\mathrm{a})}$ & $0.0011 \pm 0.0025$ & $\mathrm{BD}^{1}$ & $\begin{array}{c}0.0036 \pm \\
0.0006\end{array}$ & $\mathrm{BD}^{(\mathrm{a})}$ \\
\hline Feces $^{(b)}$ & $521 \pm 246^{(\mathrm{c})}$ & - & $942 \pm 496$ & - & $1260 \pm 431$ \\
\hline
\end{tabular}

Data are given as averages \pm S.D. $(n=18)$

(a) $\mathrm{BD}=$ below detection

(b) Feces present at end of exposure

(c) Activity recovered per plant cage

There are no given average numbers available in the literature of individual larvae that would occupy a tree during the growing season. We placed 15 larvae on each plant and observed a $15-20 \%$ loss of foliage over the 10-day exposure period. Levels of infestation in the field depend on a number of environmental variables such as temperature, species, nutritional status of the vegetation, and degree of predation (Kudo 2003). It is therefore difficult to estimate the potential for transfer, but on fresh wt, the activity of the larvae is roughly $4 \%$ of the leaves on which it feeds.

An unexpected observation during the experiment was the loss of detectable ${ }^{90} \mathrm{Sr}$ activity in the adults (Table 3.7). These insects were maintained on the contaminated plants for an additional 20 days to cover the pupation, emergence, and adult insect feeding period. Even the individual chrysali left behind by the emerging adults exhibited no detectable activity on any of the plants (Table 3.7). Moth species are capable of accumulating Sr when fed a Sr-laced sugar solution (Gu et al. 2001). Sr fed to larvae has been used as a tracer to follow insect movement (Fitt et al. 1995). The possible answer to this observation is seen in the cleared larvae (Table 3.7), which were removed from the contaminated plant and placed on leaves from control coyote willow plants grown in Hanford soil taken from near the Yakima barricade 
and free of ${ }^{90} \mathrm{Sr}$. The larvae did not contain detectable amounts of ${ }^{90} \mathrm{Sr}$ after only a 48 -h clearing period; therefore, the ${ }^{90} \mathrm{Sr}$ found in the initial sampling must have been contained in the food passing through the digestive tract at the time and was lost as it passed without being absorbed and retained. This is not to say that there is absolutely no gut $\mathrm{Sr}$ absorption from OBLR larvae, but at the concentrations of ${ }^{90} \mathrm{Sr}$ present in the leaves of plants growing in 100-N soil, there is not a high enough specific activity present to be detected in the insect. Thus, OBLR or other moth larvae that may transfer to a non-contaminated food source appear to be cleared within a short time.

It should be noted that in the adult insect, there was no detectable ${ }^{90} \mathrm{Sr}$ (Table 3.7). Adults were retained on the contaminated plants for an additional feeding period of 5-10 days. They were given no clearing period and therefore either could not feed as adults on the coyote willow leaves available to them as adults or could feed only a small amount, with the material being cleared quickly.

The larvae are active depositors of pelletized fecal material as they feed. We collected the feces from the plant and cage when the first harvest occurred. At the end of the experiment when we were able to sum the number of larvae collected as larvae or adults, we found a recovery rate of $87 \%$. From this scenario and with the feces wt collected from the cage, it was possible to calculate the amount of fecal material produced by a single larvae (Table 3.8). These calculations are rough in that the larvae present on the plants during the first 10-day exposure were of different instar stages and were growing over the period, presumably eating and defecating more as they grew. However, the calculations are informative in that the larvae appeared to eat and pass almost half of their mass (47\%) in a 24-h period (Table 3.7). Interestingly, the amount of label passed through the insect was greater than three times what the insect contained at any one time ( $4.9 \mathrm{pCi}$ in feces versus $1.4 \mathrm{pCi}$ in the uncleared larvae; Tables 3.7 and 3.8). At an infestation rate of 10 larvae/plant, up to $50 \mathrm{pCi}$ of ${ }^{90} \mathrm{Sr}$ was deposited to the soil from the insects they fed each day (for $\sim 20$ days) for a possible total of $1000 \mathrm{pCi}$, roughly three times that projected for aphid honeydew given in Table 3.6. However, this amount of contamination would also fall onto the same soil type and essentially be undetectable from the contaminant already present. As with aphid honeydew, as the plants remove the ${ }^{90} \mathrm{Sr}$ from the soil and leaves and new stems are removed from the site, the concentrations in the soil and leaves (and accordingly in the feces or honeydew) will both diminish at a similar rate.

Table 3.8. Calculated Average Larval Dry Wt, Fecal Production Rate, and ${ }^{90} \mathrm{Sr}$ Loss to Environment at Time of Harvest Following 10-Day Exposure Period to ${ }^{90} \mathrm{Sr}$ Contaminated Coyote Willows

\begin{tabular}{cccc}
\hline $\begin{array}{c}\text { Larvae Individual } \\
\text { Dry Wt } \\
(g)\end{array}$ & $\begin{array}{c}\text { Feces Production/Individual } \\
\text { Larvae/Day } \\
(g d r y w t)\end{array}$ & $\begin{array}{c}\text { Percent of Individual } \\
\text { Mass Lost as Feces/Day } \\
(\%)\end{array}$ & $\begin{array}{c}{ }^{90} \text { Sr Lost as Feces/Individual } \\
\text { Larvae/Day } \\
(p C i)\end{array}$ \\
\hline $0.0087 \pm 0.003$ & $0.0041 \pm 0.0014$ & 47.1 & $4.9 \pm 1.7$ \\
\hline $\mathrm{Wt}$ and activities are averages \pm S.D. $(\mathrm{n}=6)$ & & \\
\hline
\end{tabular}

The actual average percentage of the total ${ }^{90} \mathrm{Sr}$ recovered from each plant that was present in either the above ground portion of the plant, the uncleared larvae, or the larvae feces over the experimental period is given in Table 3.9. The data show that $\sim 4 \%$ of the ${ }^{90} \mathrm{Sr}$ extracted from the soil was lost as moth feces from the plant during the 10-day exposure. As shown above, the uncleared larvae contained very little ${ }^{90} \mathrm{Sr}$, with only $\sim 0.02 \%$ of the ${ }^{90} \mathrm{Sr}$ removed from the soil. 
Table 3.9. Plant Shoot (Trunk, Stems, and Leaves), Larval, and Fecal Activity Expressed as Both pCi of ${ }^{90} \mathrm{Sr}$ and Percent of Total Recovered ${ }^{90} \mathrm{Sr}$ for Each Plant.

\begin{tabular}{lccccc}
\hline \multicolumn{2}{c}{${ }^{90} \mathrm{Sr}$ Activity $\left(p C i{ }^{90} \mathrm{Sr}\right)$} & \multicolumn{2}{c}{ Percent of Plant-Extracted ${ }^{90} \mathrm{Sr}(\%)$} \\
\hline $\begin{array}{l}\text { Above-Ground } \\
\text { Tissue }\end{array}$ & Larvae & Feces & $\begin{array}{c}\text { Above-Ground } \\
\text { Tissue }\end{array}$ & Larvae & Feces \\
\hline $30834 \pm 10226$ & $5 \pm 3$ & $1285 \pm 470$ & $95.59 \pm 1.66$ & $0.02 \pm 0.02$ & $4.38 \pm 1.66$ \\
\hline Wts and activities are averages \pm S.D. $(\mathrm{n}=6)$ & & & \\
\hline
\end{tabular}

As a potential source of ${ }^{90} \mathrm{Sr}$, off-site transfer from the willows is the possibility that another predator could feed on the larvae as they are feeding on the leaves (Table 3.10). Such a predator could be the redwinged blackbird, which can eat 10 to $20 \mathrm{~g}$ in food (seed and insects)/day (Mason and Reidinger 1981) and weighs an average of $65 \mathrm{~g}$ (Beletsky 1996).

Table 3.10. Calculated Exposure Level of ${ }^{90} \mathrm{Sr}$ to Red-Winged Blackbirds Based on the Premise of Exclusive Feeding on Moth Larvae Eating Leaves on Coyote Willow Trees Growing at $100-\mathrm{N}$

\begin{tabular}{|c|c|c|c|c|}
\hline $\begin{array}{c}\text { Larvae/g Fresh Wt } \\
\text { (No.) }\end{array}$ & $\begin{array}{l}\text { Food Consumed by a } \\
\text { Red-Winged } \\
\text { Blackbird/Day } \\
(g \text { fresh } w t)\end{array}$ & $\begin{array}{c}\text { Larvae } \\
\text { Consumed/Day } \\
\text { (No.) }\end{array}$ & $\begin{array}{c}\text { Activity of } \\
\text { Individual Larvae } \\
\text { on Fresh-Wt Basis } \\
(p C i)\end{array}$ & $\begin{array}{c}\text { Total } \\
\text { Consumed/Day } \\
(p C i)\end{array}$ \\
\hline 20.8 & 20 & 416 & 1.4 & 666 \\
\hline
\end{tabular}

Based on data in Table 3.7, it would take 21 larvae to make $1 \mathrm{~g}$ (fresh wt). To make $32.5 \mathrm{~g}$ of food, we would need 676 larvae, and an activity of $1.4 \mathrm{pCi}$ would mean that the bird would receive a dose of nearly $1000 \mathrm{pCi} /$ day. This would also mean that in a 12-h period, the bird would have to eat 56 larvae/h, an impressive feat. While the likelihood of such an event occurring is small, it is present; therefore, effort to exclude birds from the $100-\mathrm{N}$ shoreline compound in which the willows would be placed is essential. 



\subsection{Conclusions}

Strontium-90 is a fission product of Uranium (U) processing for the production of Plutonium (Pu). As a result of over twenty years (1962 to 1986) of operations and waste management, nearly 3000 curies (Ci) of ${ }^{90} \mathrm{Sr}$ were discharged to liquid waste disposal facilities at the Hanford Site's 100-N Area. These discharges have impacted the groundwater and, through passive movement with the groundwater flow, the Columbia River shoreline and the river itself.

Currently, DOE has commenced an aggressive endeavor to protect the environment along the river. This effort includes the prevention of further ${ }^{90} \mathrm{Sr}$ transport through the groundwater using a permeable apatite barrier to immobilize the ${ }^{90} \mathrm{Sr}$ and, the possible application of coyote willow plants to phytoextract the $\mathrm{Sr}$ from the soil through the plant roots and into above-ground shoots that can be collected and removed from the site. As a native component of the Columbia's ecosystem in the Hanford area, coyote willow is a primary food producer and is therefore a natural component of the food chain of several species that also inhabit this space. The potential for off-site transfer of ${ }^{90} \mathrm{Sr}$ through the consumption of the shoots by herbivorous insects has prompted this study.

Many herbivores can be excluded from access to the plants growing in the ${ }^{90} \mathrm{Sr}$ contaminated soil through the application of engineering practices, such as differing types of fencing and management practices such as detritus collection and harvest frequency. Herbivorous insect species such as aphids and moths would be more difficult to control; therefore, we performed this work to assess the risk the insects might pose if phytoextraction was implemented at 100-N.

Controlled studies have been performed employing coyote willow plants growing in actual 100-N ${ }^{90} \mathrm{Sr}$ contaminated soil and exposed to herbivorous aphids or moth larvae. The results are summarized below:

- Coyote willows will accumulate ${ }^{90} \mathrm{Sr}$ from $100-\mathrm{N}$ soil (sediment). The plants were capable of accumulating greater than $10 \%$ of the total activity contained in the pots and transporting ${ }^{90} \mathrm{Sr}$ to the above-ground shoot within 60 days.

- Over an exposure period of 17-days, heavy infestations of aphids feeding on the stems and leaves of willows grown in $100-\mathrm{N}{ }^{90} \mathrm{Sr}$-contaminated soil can accumulate a small amount $(\sim 0.15 \pm$ $0.06 \%$, or $2.2 \pm 0.7 \mathrm{pCi}$ ) of the total ${ }^{90} \mathrm{Sr}$ removed from the soil by the plant. The ${ }^{90} \mathrm{Sr}$ in the exuded honeydew during this period amounted to $1.17 \pm 0.28 \%(2.04 \pm 0.17 \mathrm{pCi} / \mathrm{plant})$ of this total ${ }^{90} \mathrm{Sr}$ concentration. The honeydew would eventually be deposited into the soil at the base of the plant, but the activity was so dispersed as to be undetectable.

- Moth larvae feeding on ${ }^{90} \mathrm{Sr}$-contaminated leaves from $100-\mathrm{N}$ soil grown plants contained 1 to 2 pCi of ${ }^{90} \mathrm{Sr} /$ larvae. The ${ }^{90} \mathrm{Sr}$ was not retained in the insect once their digestive tracts were cleared. Pupating and adult moths also contained no detectable amounts of ${ }^{90} \mathrm{Sr}$. The lack of label may also indicate that the adults would not continue feeding on willows but seek other food sources. Over the 10-day exposure period, $\sim 0.16 \%$ of the phytoextracted ${ }^{90} \mathrm{Sr}$ was lost from the plant as moth feces. However, like the aphid honeydew, moth larvae feces dispersed into the soil were undetectable. Any loss of ${ }^{90} \mathrm{Sr}$ to the ground below the plants either as aphid honeydew or as moth larvae feces would only occur if and when the insects were present. Further with time, as 
the plant diminishes the content of ${ }^{90} \mathrm{Sr}$ in the soil with uptake and dry matter removal following harvests, the activity of the label in the leaves and new stems would also diminish.

- Moth larvae consume ${ }^{90} \mathrm{Sr}$ contaminated leaves but retain very little of the label $(\sim 0.02 \%)$ and only that contained in their digestive tracts. As the moths pupated and became adults, they contained no detectable amounts of ${ }^{90} \mathrm{Sr}$, which may indicate that they would not continue feeding on the willows but would seek other food sources. Over the 10-day exposure period, $\sim 4 \%$ of the phytoextracted ${ }^{90} \mathrm{Sr}$ was lost from the plant as moth feces. However, like the honeydew, the feces would be dispersed into the soil and would not be detectable.

- With time, as the plant diminishes the content of ${ }^{90} \mathrm{Sr}$ in the soil through root uptake, transfer to the above-ground shoot, and shoot dry matter removal following harvests, the activity of the label in the leaves and new stems would also diminish.

- Secondary consumption of insect herbivores (moth larvae) by birds as the larvae feed on the trees may present a slight risk of transfer of label present in the moth digestive tract to the bird. While $\mathrm{Sr}$ has been reported to have low or little biotransfer in laboratory feeding experiments, it has not been shown in the field definitively. A conservative approach would be to explore the use of bird netting over the fenced plot along the shoreline to restrict bird access to the plants.

The results of this study indicate that the risk for detectable transfer of ${ }^{90} \mathrm{Sr}$ from willow trees growing in the contaminated soil along the $100-\mathrm{N}$ shoreline through the food chain of herbivorous insects is slight to non-existent. 


\subsection{Literature Cited}

Ainsworth CC and RJ Fellows. 2007. Strontium-90 Phytoremediation Study Final Report. PNNL-16714, Pacific Northwest National Laboratory, Richland, WA.

Angelidis TN. 1997. "Comparison of Sediment Pore Water Sampling for Specific Parameters Using Two Techniques.” Water, Air, and Soil Pollution 99(1-4):179-185.

Antonio EJ, TM Poston, and WH Rickard, Jr. 1993. Radiological Survey of Shoreline Vegetation from the Hanford Reach of the Columbia River, 1990-1992. PNL-8797, Pacific Northwest National Laboratory, Richland, WA.

Barton-Browne, L and D Raubenheimer. 2003. "Ontogenetic Changes in the Rate of Ingestion and Estimates of Food Consumption in Fourth and Fifth Instar Helicoverpa armigera Caterpillars." Journal of Insect Physiology 49:63-71.

Beletsky L. 1996. The Red-Winged Blackbird: The Biology of a Strongly Polygynous Songbird. Academic Press, New York, NY. 314 pp.

Carraca S, A Ferreira, and J Coimbra. 1990. "Sr Transfer Factors Between Different Levels in the Trophic Chain in Two Dams of Douro River (Portugal)." Water Research 24(12):1497-1508.

Carter-Wientjes CH, JS Russin, DJ Boethel, JL Griffin, and EC McGawley. 2004. "Feeding and Maturation by Soybean Looper (Lepidoptera noctuidae) Larvae on Soybean Affected by Weed, Fungus, and Nematode Pests." Journal of Economic Entomology 97(1):14-20.

Casadesus J, T Sauras-Year, and VR Vallejo. 2008. "Predicting Soil-to-Plant Transfer of Radio Nuclides with a Mechanistic Model (BioRUR).” Journal of Environmental Radioactivity 99:864-871.

Chojnacka K, A Chojnacki, H Gorecka, and H Gorecki. 2005. "Bioavailability of Heavy Metals from Polluted Soils to Plants." Science of the Total Environment 337(1-3):175-182.

Crawford, LA, NW Lepp, and ID Hodkinson. 1996. “Accumulation and Egestion of Dietary Copper and Cadmium by the Grasshopper Locusta migratoria, R\&F (Orthoptera: Acrididae).” Environmental Pollution 92(3):241-246.

Dixon AFG. 1975. "Aphids and Translocation." Transport in Plants I: Phloem Transport. MH Zimmerman and JA Milburn, eds. Encyclopedia of Plant Physiology New Series Vol. 1. Springer-Verlag, New York, NY. pp. 154-170.

DOE - U.S. Department of Energy. 2005. Strontium-90 Treatability Test Plan for 100-NR-2

Groundwater Operable Unit. DOE/RL-2005-96, Draft A, U.S. Department of Energy, Richland, WA.

Douglas AE. 2006. "Phloem-Sap Feeding by Animals: Problems and Solutions." Journal of Experimental Botany 57(4):747-754.

Dutton MV and PN Humphreys. 2005. "Assessing the Potential of Short Rotation Coppice (SRC) for Cleanup of Radionuclide-Contaminated Sites." International Journal of Phytoremediation 7(4):279-293. 
Ehlken S and G Kirchner. 2002. "Environmental Processes Affecting Plant Root Uptake of Radioactive Trace Elements and Variability of Transfer Factor Data: A Review." Journal of Environmental Radioactivity 58:97-112.

Esau K. 1965. Plant Anatomy. John Wiley \& Sons, New York, NY.

Fisher DB. 1983. "Year-Round Collection of Willow Salix exigua Sieve Tube Exudate." Planta 159(6):529-533.

Fitt GP, ML Dillon, and JG Hamilton. 1995. "Spatial Dynamics of Helicoverpa Populations in Australia Simulation Modeling and Empiracal-Studies of Adult Movement." Computers and Electronics in Agriculture 13(2):177-192.

Gollany HT, PR Bloom, and TE Schumacher. 1997. "Rhizosphere Soil-Water Collection by Immiscible Displacement-Centrifugation Technique.” Plant and Soil 188(1):59-64.

Gu HN, F Wackers, P Steindl, D Gunther, and S Dorn. 2001. "Different Approaches to Labeling Parasitoids Using Strontium.” Entomology Experiment et Application 99(2):173-181.

INEEL - Idaho National Engineering and Environmental Laboratory. 2000. Proceedings from the Workshop on Phtyoremediation of Inorganic Contaminants. INEEL/EXT-2000-00207, February 2000, November 30-December 2, 1999, Argonne National Laboratory, Chicago, IL, Idaho National Engineering and Environmental Laboratory, Idaho Falls, ID.

Johnson PC and RM Reeves. 1995. "Incorporation of the Biological Marker Rubidium in Gypsy Moth (Lepidoptera: Lymantriidae) and its Transfer to the Predator Carabus nemoralis (Coleoptera: Carabidae)." Environmental Etymology 24(1):46-51.

Jolanta MP, P Wojciech, O Beata, A Maria, N Miroslaw, and M Pawel. 2002. "Trace Elements in the Chrysomelid Beetle (Chrysolina pardalina) and its Ni-Hyperaccumulating Host-Plant (Berkheya coddii)." Fresenius Environmental Bulletin 11(2):78-84.

Jost DJ and HN Pitre. 2002. "Activity of Rubidium and Cesium in Soybean Looper (Lepidoptera noctuidae): Insect Feeding on Cotton and Soybean Measured by Elemental Markers. Journal of Economic Entomology 95(2):278-285.

Jouvre A, M Lejune, and J Rey. 1999. "A New Method for Determining the Bioavailability of Radio nuclides in the Soil Solution." Journal of Environmental Radioactivity 43:277-289.

Kozlov MV, E Haukioja, and EF Kovnatsky. 2000. "Uptake and Excretion of Nickel and Copper by LeafMining Larvae of Eriocrania semipurpurella (Lepidoptera: Eriocranlidae) Feeding of Contaminated Birch Foliage.” Environmental Pollution 108(2):303-310.

Kudo G. 2003. "Variations in Leaf Traits and Susceptibility to Insect Herbivory Within a Salix miyabeana Population Under Field Conditions." Plant Ecology 169:61-69.

Kuffner M, M Puschenreiter, G Wieshammer, M Gorfer, and A Sessitsch. 2008. "Rhizosphere Bacteria Affect Growth and Metal Uptake of Heavy Metal Accumulating Willows." Plant and Soil 304(1-2):3544. 
Lorenz SE, RE Hamon, and SP McGrath. 1994. "Differences Between Soil Solutions Obtained From Rhizosphere and Non-Rhizosphere Soils by Water Displacement and Soil Centrifugation.” European Journal of Soil Science 45(4):431-438.

Mason JR and RF Reidinger Jr. 1981. "Effects of Social Facilitation and Observational Learning on Feeding Behavior of the Red-Winged Blackbird (Agelaius phoeniceus)." Auk 98(4):778-784.

Mietelski JW, P Szwalko, E Tomankiewicz, P Gaca, S Malek, J Barszcz, and S Grabowska. 2004. “137Cs, ${ }^{40} \mathrm{~K},{ }^{90} \mathrm{Sr},{ }^{238,239+}{ }^{240} \mathrm{Pu},{ }^{241} \mathrm{Am}$, and ${ }^{243+244} \mathrm{Cm}$ in Forest Litter and Their Transfer to Some Species of Insects and Plants in Boreal Forests: Three Case Studies." Journal of Radioanalytical and Nuclear Chemistry 262(3):645-660.

Peel AJ. 1975. "Investigations with Aphid Stylets into the Physiology of the Sieve Tube." In Transport in Plants I: Phloem Transport. MH Zimmerman and JA Milburn, eds. Encyclopedia of Plant Physiology New Series Vol. 1. Springer-Verlag, New York, NY. pp. 171-195.

Pilon-Smits E. 2005. "Phytoremediation.” Annual Review of Plant Biololy 56:15-39.

Poston TM, RW Hanf, and RL Dirkes, eds. 2000. Hanford Site Environmental Report for Calendar Year 1999. PNNL-13230, Pacific Northwest National Laboratory, Richland, WA.

Pulford ID and C Watson. 2003. "Phytoremediation of Heavy Metal-Contaminated Land by Trees - A Review." Environment International 29:529-540.

Reichle DE and DA Crossley Jr. 1969. "Trophic Level Concentrations of Cesium-137, Sodium, and Potassium in Forest Arthropods." Proceedings of the Ecological Society of America's Second National Symposium on Radioecology. DJ Nelson and FC Evans, eds. CONF-670503, USAEC, Washington, DC. pp. 678-686.

Serne RJ and VL LeGore. 1996. Strontium-90 Adsorption-Desorption Properties and Sediment Characterization at the 100-N Area. PNL-10899, Pacific Northwest National Laboratory, Richland, WA.

Showers WB, RB Smelser, AJ Keaster, F Robinson, JD Lopez, and SE Taylor. 1989. "Recapture of Marked Black Cutworm (Lepidoptera noctuidae) Males After Long-Range Transport." Environmental Entomology 18(3):447-458.

Spencer JL, TR Mabry, and TT Vaughn. 2003. "Use of Transgenic Plants to Measure Insect Herbivore Movement." Journal of Economic Entomology 96(6):1738-1749.

Sysoeva AA, IV Konopleva, and NI Sanzharova. 2005. "Bioavailability of Radiostrontium in Soil: Experimental Study and Modeling." Journal of Environmental Radioactivity 81:269-282.

Trichilo PJ and TP Mack. 1989. "Soybean Leaf Consumption by the Soybean Looper Lepidoptera noctuidae as a Function of Temperature Instar and Larval Weight." Journal of Economic Entomology 82(2):633-638.

Vandenhove H. 2006. "Phytomanagement of Radioactively Contaminated Sites." Phytoremediation of Metals-Contaminated Soils. NATO Science Series IV. Earth and Environmental Sciences. JL Morel, G Echevarria, and N Goncharova, eds. Springer-Verlag, New York, NY. Chapter 6, pp. 191-228. 
Van Verst SP, CL Albin, GW Patton, and ML Blanton. 1998. Survey of Radiological Contaminants in the Near-Shore Environment at the Hanford Site 100-N Reactor Area. PNNL-11933, Pacific Northwest National Laboratory, Richland, WA.

Van Bel AJE. 1990. "Xylem-Phloem Exchange via the Rays: The Undervalued Route of Transport." Journal of Experimental Botany 41(6):631-644.

White PJ. 2001. "The Pathways of Calcium Movement to the Xylem." Journal of Experimental Botany 52(358):891-899.

Willey N and C Collins. 2007. "Phytoremediation of Soils Contaminated with Radionuclides." Radiation in the Environment 10:43-69.

Will T and AJE Van Bel. 2006. "Physical and Chemical Interactions Between Aphids and Plants." Journal of Experimental Botany 57(4):729-737.

Zeigler H. 1975. "Nature of Transported Substances." Transport in Plants I: Phloem Transport. MH Zimmerman and JA Milburn, eds. Encyclopedia of Plant Physiology New Series Vol. 1. Springer-Verlag, New York, NY.

Zimmerman MH. 1969. "Movement of Organic Substances in Trees.” Science 133:73-79. 


\section{Distribution}

No. of

Copies

Offsite

RB Rowley

Office of Groundwater and Soil

Remediation

EM-22/Cloverleaf Building

U.S. Department of Energy

1000 Independence Avenue, S.W.

Washington, D.C. 20585-2040

PJ Landolt

Research Leader

USDA-ARS Yakima Agricultural Research

Station

5230 Konnowac Pass Road

Wapato, WA 98951
No. of

Copies

Onsite

3

U.S. Department of Energy

Richland Operations Office

M Thompson (3)

A6-38

CH2M Hill Plateau Remediation Company

WF Barrett

R3-60

Washington State Department of Ecology

Ecology Hanford Project Office

D Goswami

HO-57

$7 \quad$ Pacific Northwest National Laboratory

CJ Driver

K2-21

RJ Fellows (5)

K2-21

JS Fruchter (2)

Distr.1 




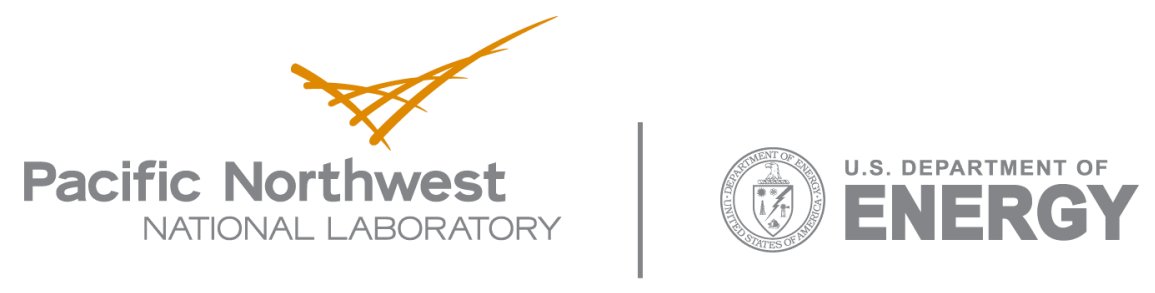

902 Battelle Boulevard

P.O. Box 999

Richland, WA 99352

1-888-375-PNNL (7665)

www.pnl.gov 